УДК 021.63:001:061.12(47+57)(091)《1930/1945»

https://doi.org/10.20913/2618-7575-2021-1-9-35

\author{
СОЗДАНИЕ И РАЗВИТИЕ СИСТЕМЫ БИБЛИОТЕК ФИЛИАЛОВ \\ И БАЗ АКАДЕМИИ НАУК СССР: 1930-е -1945 гГ.
}

\title{
ESTABLISHING AND DEVELOPING THE SYSTEM OF LIBRARIES OF THE USSR ACADEMY OF SCIENCES REGIONAL BRANCHES: THE 1930s-1945
}

\begin{abstract}
(с) Левнер Михаил Вениаминович
кандидат технических наук, заслуженный работник культуры РФ, заведующий отделом редких изданий и архивных документов, Библиотека по естественным наукам Российской академии наук (БЕН РАН), Москва, Россия, levnermv@yandex.ru
\end{abstract}

\section{(c) Виноградова Наталья Андреевна}

главный библиотекарь отдела редких изданий и архивных документов, Библиотека по естественным наукам Российской академии наук (БЕН РАН), Москва, Россия, bornfreee@yandex.ru

Статья посвящена организации работы библиотек Академии наук (АН) СССР в 1930-е годы при создании сети научных филиалов и баз АН в разных регионах страны. Главной целью создаваемой библиотечной системы являлось обеспечение научными изданиями ученых, работающих вдали от Москвы и Ленинграда в соответствии со специализацией вновь создаваемых научных учреждений. Предпринята попытка напомнить читателям, как начиналось расширение системы академических библиотек в СССР, приводятся фактические данные об их работе на основе найденных архивных документов. Дается обзор деятельности созданных на периферии академических организаций, описаны процессы комплектования и методического руководства библиотеками филиалов и баз АН СССР. Заложенные в 1930-е гг. принципы формирования сети академических библиотек получили в дальнейшем свое развитие, доказали свою эффективность в течение многих десятилетий. Фактографической базой статьи стали документы, выявленные в архиве Библиотеки по естественным наукам Российской академии наук (БЕН РАН), Московском и Санкт-Петербургском архивах РАН, региональных архивах, и материалы, доступные в интернете. Авторы использовали общенаучную методологию, применяя источниковедческий, археографический и аналитико-синтетический методы работы с архивными документами.

Ключевые слова: Академия наук СССР, библиотека, библиотечные системы, библиотекари, архивы

\author{
Levner Mikhail Veniaminovich \\ Candidate of Technical Sciences, Head of the \\ Department of Rare Publications and Archival \\ Documents, Library for Natural Sciences of the \\ Russian Academy of Sciences (LNS RAS), Moscow, \\ Russia, levnermv@yandex.ru
}

\section{Vinogradova Natalia Andreevna \\ Chief Librarian of Department of Rare Publications and Archival Documents, Library for Natural Sciences of the Russian Academy of Sciences (LNS RAS), Moscow, Russia,bornfreee@yandex.ru}

The article is devoted to organizing the work of the USSR Academy of Sciences (AS) libraries in the 1930s, while creating a network of scientific branches and bases of AS in the country regions. The main goal of the created library system was to provide scientists working far from Moscow and Leningrad with scientific publications according with the specialization of newly created scientific institutions. The article attempts to recall how the expansion of the system of academic libraries in the USSR has started, and provides real data on their work. The authors overview the academic organizations created on the periphery, describes the processes of acquisitions and methodological management of libraries of branches and bases of the USSR Academy of Sciences.The principles of formation of science library network proved to be effective and the system of academic libraries expanded successfully for decades.

The factual base of the article were the documents found in the archives of the Library of Natural Sciences RAS, in the Moscow and St. Petersburg Archives of the Russian Academy of Sciences, in some regional archives and materials available on the Internet sites. The authors used a general scientific methodology, applying source study, archaeographic and analytical-synthetic methods of working with archival documents.

Keywords: USSR Academy of Sciences, library, library systems, librarians, archives 


\section{Введение}

В 2024 г. в стране будет отмечаться 300-летний юбилей Российской академии наук (РАН). Для подготовки юбилейных торжеств были изданы Указ Президента РФ от 06.05.2018 г. № 197 «О праздновании 300-летия Российской академии наук» и Распоряжение Правительства РФ от 20 ноября 2018 г. № 2518-р об «Образовании организационного комитета по подготовке и проведению празднования 300-летия Российской академии наук и утверждении его состава».

Для Библиотеки по естественным наукам (БЕН) РАН подготовка к юбилею имеет особое значение, поскольку в 2023 г. исполняется 50 лет самой библиотеке, а в 2024 г. - 90 лет с момента создания предшественника БЕН РАН - Сектора сети специальных библиотек, созданного в 1934 г. для информационного обслуживания переведенных из Ленинграда в Москву академических учреждений естественнонаучного профиля. В рамках подготовки к предстоящим юбилеям освещается история создания и развития информационного обеспечения исследований по естественно-научной тематике в расширяющейся структуре Академии наук (АН) СССР.

\section{Создание системы филиалов и баз АН СССР}

На протяжении всего существования РАН неотъемлемыми составляющими ее деятельности являлись экспедиции ученых и, по мере надобности, организация научных станций на местах. Продолжилась эта работа и в советское время. Так, например, в 1926 г. АН СССР проводила экспедиционные работы в Казахстане и Туркмении, а также в Карельской, Таджикской и Якутской автономных республиках. В последующие годы экспедиционная деятельность приобрела комплексный характер, к ее работе стали привлекаться местные специалисты, для чего АН СССР начала подготовку для исследований национальных кадров.

С объявления первой пятилетки в СССР повсеместно росло количество неакадемических научных учреждений, и Академия наук - самая авторитетная и обширная научная организация страны - не могла остаться в стороне. К тому же по сравнению с неакадемическими учреждениями у Академии было неоспоримое преимущество - ее полидисциплинарность, то есть возможность создавать комплексные учреждения, проводящие научную работу в самых различных отраслях знания.

Вопрос о необходимости организации на местах сети исследовательских учреждений, связанных с АН, был поднят еще в 1929 г. при обсуждении деятельности академических учреждений на Общем собрании АН СССР. Академик А. Е. Ферсман выразил тогда общее мнение так: «Мы не можем изучение крупных проблем и отдельных районов ставить оторванно, кабинетно. Мы должны решительным образом приблизить наши исследования к самой природе; к тому производству, в интересах которого протекает работа, ко всему укладу и потребностям местного хозяйства» ${ }^{1}$. В течение следующего года в АН СССР была разработана конкретная программа создания академических учреждений в регионах страны. В мае 1931 г. вышло Постановление Президиума АН СССР с признанием «принципиально необходимым <...> приступить к созданию ряда исследовательских комплексных баз АН и сети специальных исследовательских станций...» ${ }^{2}$.

13 июля 1931 г. непременный секретарь АН СССР академик В. П. Волгин в докладе Президиуму ЦИК СССР изложил разработанный АН СССР детальный план создания академических учреждений на периферии, а 30 июля 1931 г. соответствующее постановление издал Комитет по заведованию учеными и учебными учреждениями ЦИК СССР (рис. 1).

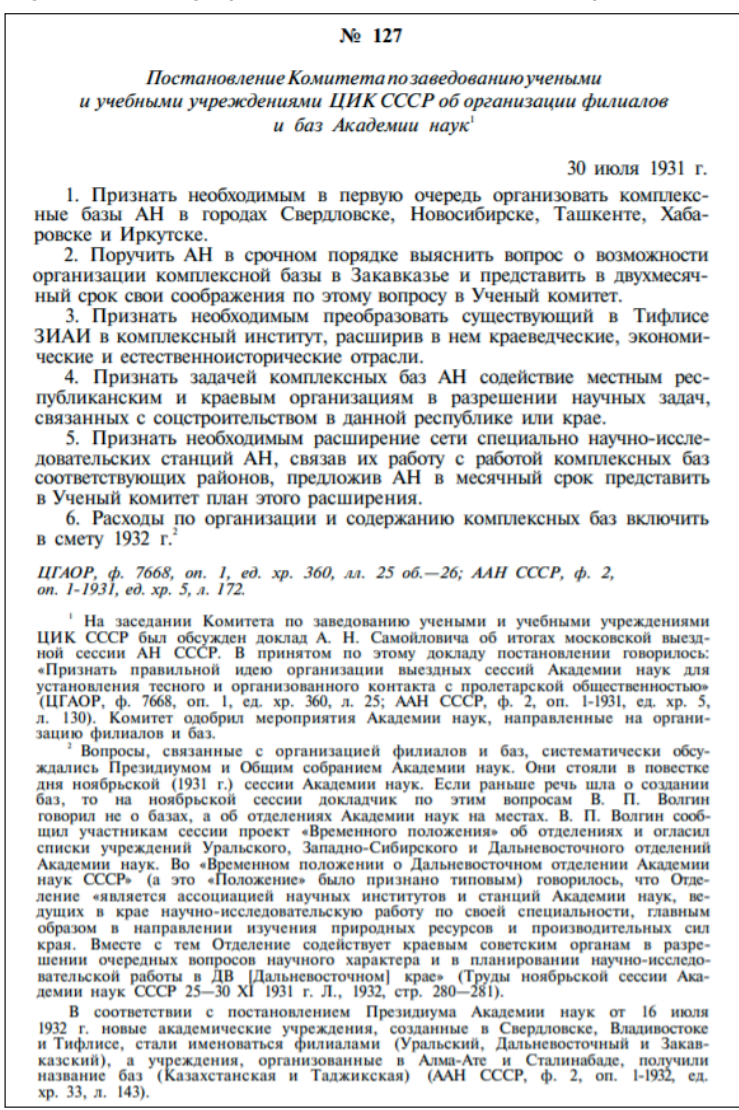

Рис. 1. Постановление Комитета

по заведованию учеными и учебными учреждениями ЦИК СССР [1]

Санкт-Петербургский филиал Архива Российской академии наук. Ф. 2. Оп. 1 (1929). Д. 126. Л. 30-36. Стенографический отчет общего совещания АН СССР.

Санкт-Петербургский филиал Архива Российской академии наук. Ф. 2. Оп. 1 (1931). Д. 31. Л. 119. Протоколы Президиума (подписные). 
Впоследствии функция создания научных организаций была законодательно закреплена в параграфе 5 Устава АН СССР 1935 г.: «Академия наук учреждает в своем составе исследовательские институты, библиотеки, музеи, лаборатории, кабинеты и комиссии, а также филиалы и базы на местах и принимает все меры к тому, чтобы эти учреждения Академии были обеспечены высококвалифицированным научным составом и соответствующим оборудованием» [2].

В 1931 г. для руководства работой по организации баз и филиалов при Президиуме АН СССР была создана Комиссия по базам, которую возглавил вице-президент АН СССР академик В. Л. Комаров. В 1935 г. Комиссия значительно расширила свои функции и была переименована в Комитет по заведованию филиалами и базами АН СССР.

1932 г. стал годом организационного строительства академических учреждений на местах в регионах СССР, а 1933-й - годом развертывания научной деятельности филиалов и баз. Уже на 1 января 1934 г. было издано более 100 печатных листов научных работ их сотрудников. В 1934 г. филиалы и базы уже представляли собой самостоятельные научно-исследовательские организации, но развивались они неравномерно, о чем свидетельствуют архивные материалы, один из фрагментов которых приведен на рисунке 2.

Таким образом, в 1932-1938 гг. разворачивается работа по созданию и развитию академических учреждений в разных регионах страны ${ }^{3}$.

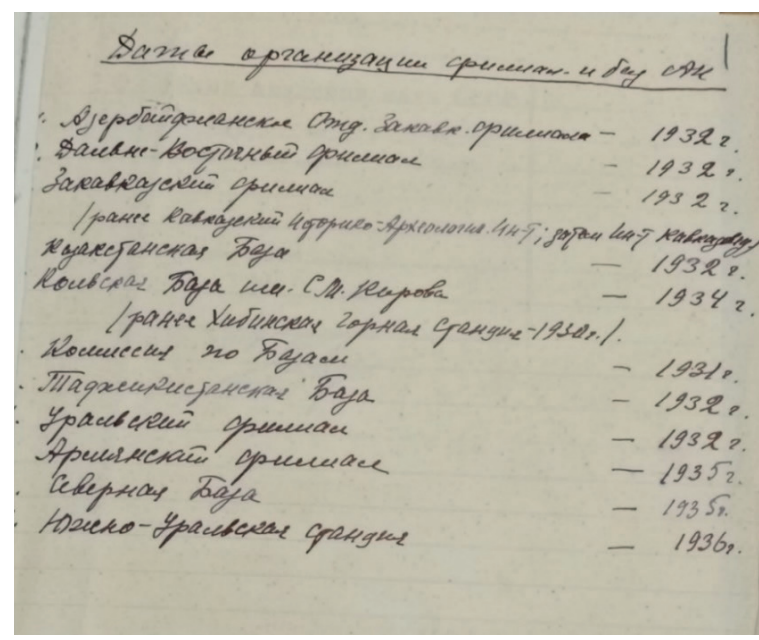

Pис. 2. Список планируемых к созданию филиалов и баз АН СССР. Источник: Архив Российской академии наук. Ф. 188. Оп. 1 (1931-1942). Д. 350. Л. 1. Список филиалов и баз с датами их организации

Уже существующие научные станции со временем получают статус учреждений Академии наук. В 1934 г. таковыми стали Горнотаежная станция на Дальнем Востоке и Хибинская горная станция, в 1935 г. - Лимнологическая станция Листвянка на Байкале.
В конце 1932 г. было сформировано Дальневосточное отделение АН СССР, в 1933 г. Закавказский ${ }^{4}$, Уральский и Казахский филиалы, в 1934 г. - основана Таджикская база, Хибинская горная станция АН СССР была преобразована в Кольскую научно-исследовательскую базу АН СССР имени С. М. Кирова, в 1936 г. - принято решение о создании филиала АН СССР в Западно-Сибирском крае и начата организация Туркменского филиала. В 1938 г. создается верхневолжский филиал АН СССР - «БОРОК»; в 1939 г. Южно-Уральская горная станция и Узбекский филиал, в начале 1941 г. - Туркменский филиал. Правда, Дальневосточное отделение АН СССР в 1939 г. было ликвидировано, продолжала действовать только Горно-таежная станция ${ }^{5}$.

В 1938 г. положение филиала АН СССР закрепляется законодательно - утвержден Устав филиала AH CCCP.

«Сеть филиалов академии наук возникла закономерно, как естественное следствие происшедшей после установления советской власти идейной перестройки в работе Академии и поворота ее к практическим вопросам жизни, к активному участию в хозяйственном и культурном социалистическом строительстве», - напишет впоследствии академик И. П. Бардин [3]. Для проведения полноценных научных исследований и их информационного обеспечения во всех создаваемых организациях были необходимы научные библиотеки, учреждение которых мы и рассмотрим далее.

\section{Сеть библиотек филиалов и баз АН СССР в 1930-е гг.}

Создаваемые в АН СССР базы, как правило, работали по одной научной теме, а филиалы объединяли несколько научных учреждений с разными научными темами. Некоторые из них - например, Дальневосточное отделение и Хибинская горная станция, преобразованная в Кольскую базу им. С. М. Кирова 6 , - уже имели в своем составе библиотеки, но в большинстве филиалов и баз их пришлось организовывать с нуля. Эта задача была поручена Библиотеке Академии наук (БАН) в Ленинграде, поскольку все библиотеки академических учреждений с момента создания входили в ее библиотечную сеть. 5 ноября 1937 г. Президиум АН СССР на своем заседании подтвердил, что «библиотека АН едина и состоит из центральной библиотеки, которой принадлежит руководящая роль, и сети специальных библиотек.

\footnotetext{
В 1935 г. Закавказский филиал разделен на Азербайджанский, Армянский и Грузинский филиалы. 5 Архив Российской академии наук. Ф. 188. Оп. 1 (19311942). Перечень дел описи. Л. 99.

6 Основой библиотеки Кольской базы стала личная библиотека академика А. Е. Ферсмана, переданная базе в дар в 1932 г.
} 
В эту сеть входят библиотеки отделений, групп, филиалов и институтов» ${ }^{7}$.

Формировать библиотеки приходилось на всей обширной территории СССР. В Закавказье в Грузии и Азербайджане - новые академические учреждения создавались на основе уже работающих лабораторий, отделов, ботанических садов и исследовательских институтов, при которых были и библиотеки. В Грузии это Геофизический институт, Институт прикладной химии, Ботанический сад, Почвенная лаборатория и Абастуманская обсерватория со своими библиотеками, самой старой из которых была Библиотека Тбилисского Ботанического института, основанного в 1895 г. В ее фонде, включавшем ценные частные коллекции, находилось 30000 библиотечных единиц, в обменном фонде 20000 изданий по ботанике, сельскому хозяйству, лесоводству. Эта библиотека вела обширный книгообмен с отечественными и зарубежными научными учреждениями.

Библиотека Геофизического института Грузинского филиала АН СССР была основана в 1934 г., насчитывала 5654 библиотечных единицы, она рассылала свой «Сейсмический бюллетень» в 190 зарубежных библиотек и вела обмен с 72 учреждениями СССР. Ее единственный сотрудник Нина Порфирьевна Бараташвили составила алфавитный и систематический каталоги на весь фонд (причем в основу систематического каталога была положена Брюссельская система классификации), а также сводную картотеку иностранных периодических изданий Тбилисских научных библиотек.

Библиотека Химического института, основанная в 1930 г. и имевшая в своем фонде 8029 отечественных и 738 иностранных книг, а также 788 отечественных и 871 иностранный журнал, в свое время получила из Финляндии библиотеку профессора А. И. Садовского в количестве 1392 библиотечных единиц, а в начале 1940 г. - часть библиотеки и архив профессора Г. Н. Николадзе.

Целенаправленное комплектование библиотеки Абастуманской обсерватории (рис. 3) началось в 1932 г. с получения комплектов 15 отечественных и 34 иностранных журналов. В 1940 г. в ее фонде было уже 5000 книг и 400 названий журналов по астрономии, физике и математике. Центральная библиотека Грузинского филиала была основана только в 1941 г.

Библиотекой с самым большим фондом среди учреждений АН СССР в Закавказье - 127763 библиотечные единицы - являлась Фундаментальная библиотека Азербайджанского филиала АН СССР,

Архив Российской академии наук. Ф. 2. Оп. 6. Д. 8. Л. 125-126. Протоколы заседаний Президиума Академии наук СССР за 1937 год, том 3 (сентябрь - декабрь).

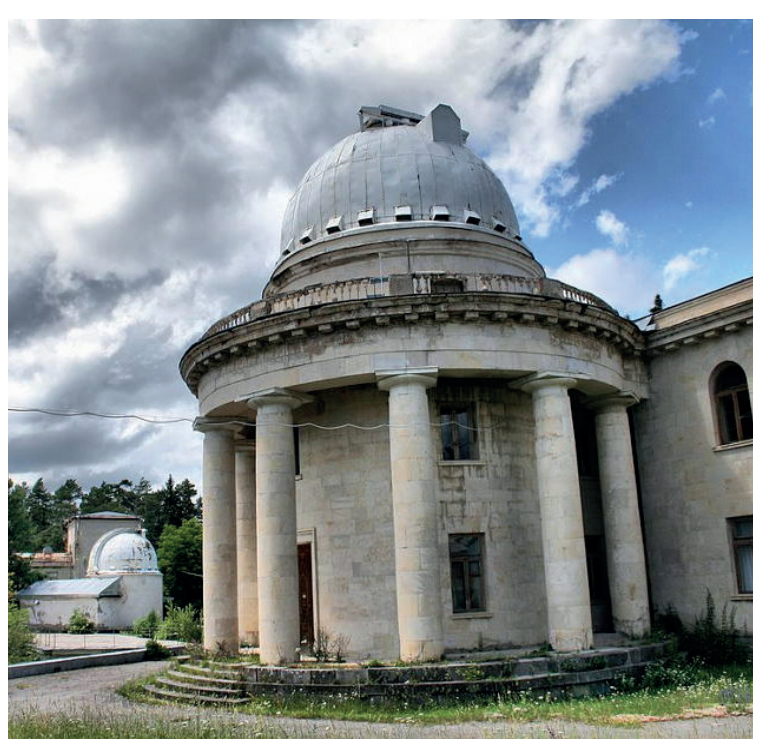

Puc. 3. Абастуманская обсерватория и библиотека

основанная в 1934 г. Ее штат насчитывал 15 человек, на комплектование ежегодно выделялось 50000 рублей. На ее базе были основаны библиотеки Института истории, археологии и этнографии (1936 г.), Зоологического и Геологического институтов (1937 г.), Института азербайджанской литературы и языка им. Низами (1939 г.). Фонды этих новых тогда библиотек не превышали 9000 библиотечных единиц. Библиотека Ботанического института, основанного в 1935 г. на базе Ботанического отдела Закавказского филиала АН СССР, имела общий фонд 18575 библиотечных единиц. Библиотека вела книгообмен со 130 учреждениями СССР и заграницы.

Азербайджанский филиал АН СССР (рис. 4) в 1934 г. имел в своем составе естественнонаучный, гуманитарный и научно-технический отделы, каждый из которых состоял из нескольких секторов. В том же году Азербайджанскому филиалу было передано одно из красивейших зданий Баку - Дворец тюркской культуры.

Армянский филиал АН СССР был представлен только одной библиотекой Геологического института (рис. 5), открытой для читателей в 1939 г., хотя литература накапливалась в Институте с момента его открытия. В 1935 г. библиотека располагала отечественным фондом в 2516 книг и 522 журнала и 387 иностранных изданий.

Во исполнение постановления Президиума АН СССР о посылке бригад ученых ${ }^{8}$ для помощи и консультации филиалам в апреле 1934 г. в Закавказский филиал из Ленинграда отправились химики Н. С. Курнаков, О. Е. Звягинцев

\footnotetext{
8 Отметим, что в Закавказский филиал и консультанты, и проверяющие ездили весьма охотно. Каждый сентябрь туда на месяц отправлялась для проверки комиссия, состоящая из крупных ученых и видных функционеров АН СССР.
} 


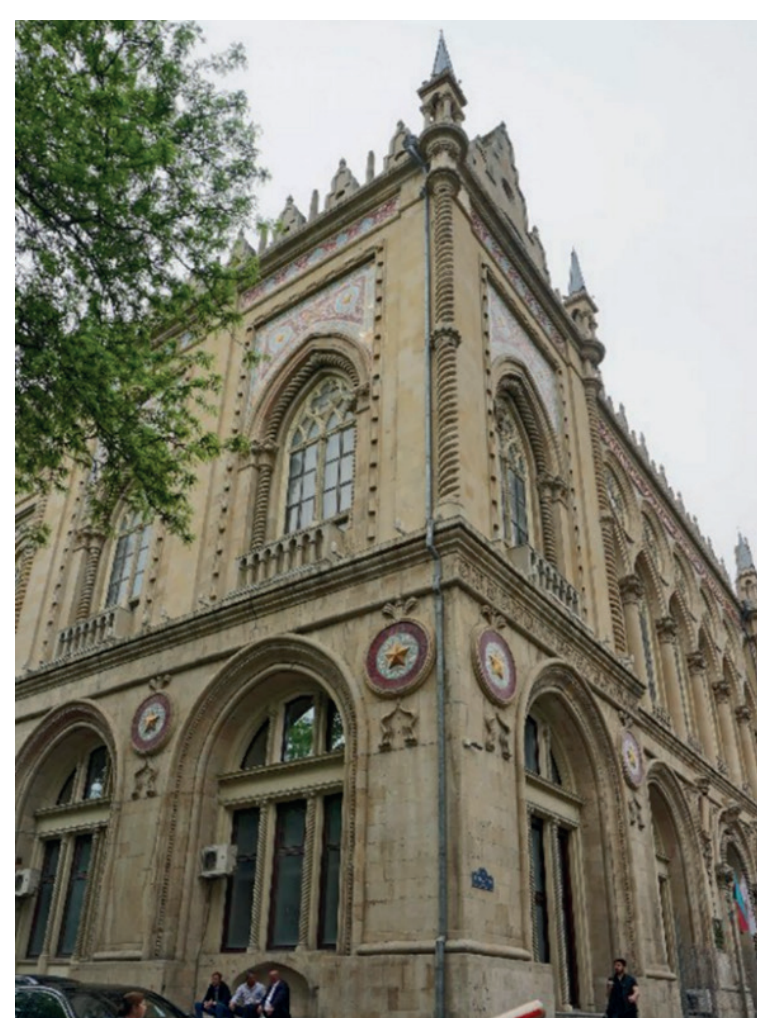

Pис. 4. Старое здание Азербайджанского филиала АН СССР. Источник: https://i.postimg. cC/K8YCrT7Y/10-DSC04496.jpg

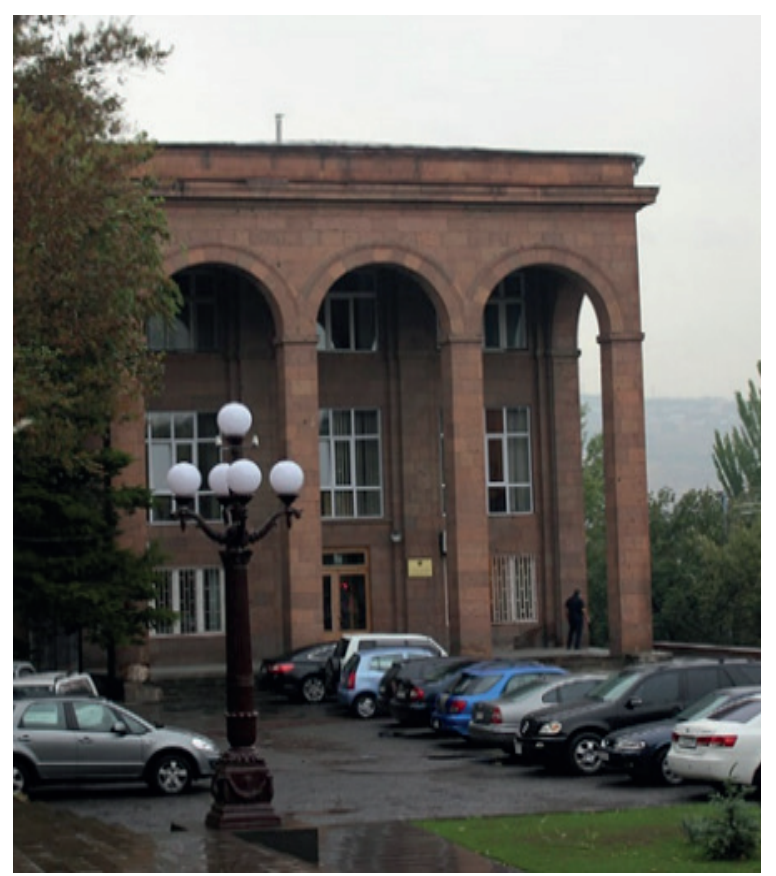

Puc. 5. Геологический институт АН в Ереване. Источник: https://upload. wikimedia.org/wikipedia/commons/ thumb/6/6b/Armenian_National_Academy_ of_Sciences_\%28Institute_of_Geology\%29_03. jpg/1599px-Armenian_National_Academy_of_ Sciences_\%28Institute_of_Geology\%29_03.jpg и еще 4 человека. Бригада посетила Баку для помощи Азербайджанскому филиалу. В результате работы командированных ученых в Грузии укрепились научные связи между Тифлисским химическим институтом, его библиотекой и химическими учреждениями АН СССР в Ленинграде, активизировалась книгообменная деятельность. Однако библиотечные специалисты для помощи в организации работы библиотек в эти комиссии не включались. С 1939 г. начали вести книгообмен библиотека Геологического института Азербайджанского филиала АН СССР с фондом 11948 библиотечных единиц (издания института были разосланы в 7 библиотек) и библиотека Химического института Грузинского филиала АН СССР с фондом 10426 библиотечных единиц. Издания были разосланы в 70 отечественных учреждений, в обмен поступила литература из 35 библиотек.

Созданию Казахстанского филиала АН СССР (рис. 6) послужило проведение в 1932 г. трех научных экспедиций. По итогам их работы в 1932 г. было подготовлено 15 научных статей, а позднее организована Комиссия экспедиционных исследований, которая объединила все экспедиции АН СССР, действующие в Казахстане. В 1934 г. в Казахстанское отделение входили уже Ботанический и Зоологический секторы и небольшая химическая лаборатория. Развертыванию работы мешало отсутствие квалифицированных кадров, оборудования и полноценной научной библиотеки. Для укомплектования базы кадрами Президиум АН СССР выделил в 1934 г. 11 специалистов, заканчивающих аспирантуру по специальностям геология и геохимия. Библиотека Казахстанского филиала была основана в 1933 г. с нуля, то есть в ее основе не было ни фондов других научных учреждений, ни полученных в дар книжных коллекций. Первоначально в созданной библиотеке имелось всего 7000 отечественных изданий, но вовсе не было иностранных, отсутствовали и самые необходимые справочные издания. Комплектованием этой многопрофильной библиотеки ${ }^{9}$ занималось в основном Издательство Академии наук, чем и объясняется тот факт, что на 1 января 1940 г. в ее фонде было уже 30000 отечественных изданий и 2375 иностранных. Позднее библиотека получила разрешение и средства на закупку литературы в библиотечном коллекторе и книжном магазине ${ }^{10}$.

Созданная в марте 1932 г. Таджикская база АН СССР за 2 года превратилась в комплексную научно-исследовательскую организацию. В ее составе действовали геохимический, ботанический, зоологический и паразитологический,

\footnotetext{
Естественные науки, техника, история, география, литература и языкознание.

10 Архив Российской академии наук. Ф. 188. Оп. 1 (19311935). Д. 17. Отчет о деятельности филиалов и баз АН СССР за время с 1932 по 1934 год. Л. 18.
} 


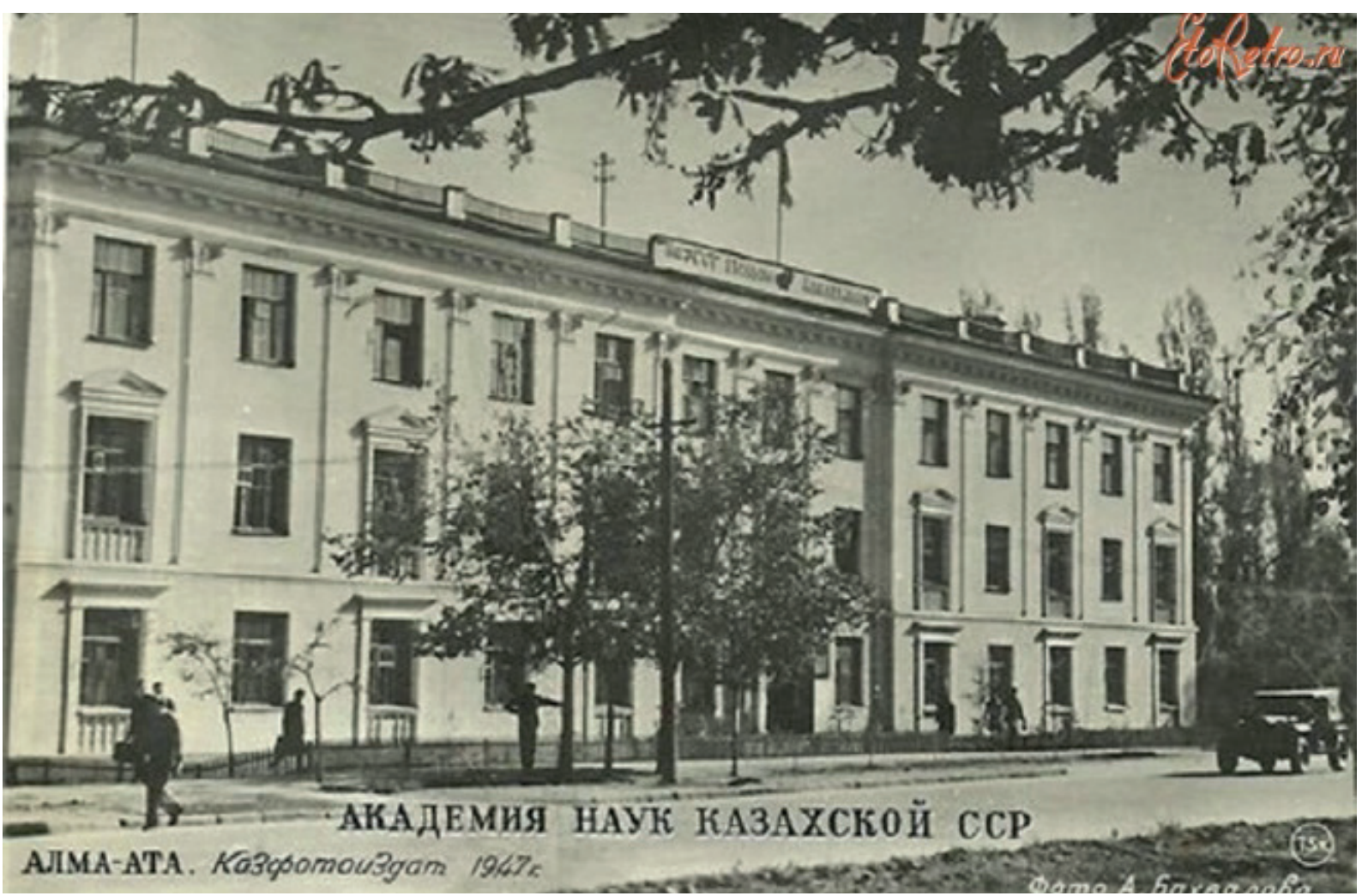

Pис. 6. Здание Казахского филиала АН СССР с библиотекой (1947 г.)

историко-лингвистический секторы, а также сектор языка и материальной культуры. Если при основании базы в ней работало всего 20 человек, то в 1933 г. - уже 61. За 2 года была основана геохимическая станция в Ходженте (рис. 7) и пункт Памирской экспедиции.

На примере Таджикской базы можно проследить, с каким трудом создавалась научная библиотека в этом новом академическом учреждении. У ее истоков стоял известный ботаник, биолог и географ Борис Алексеевич Федченко, назначенный заведующим Биологическим сектором Таджикской базы АН СССР в Сталинабаде (ныне Душанбе). Еще до официального открытия базы в 1932 г. семидесятилетний ученый составляет первые списки необходимых книг по геологии, почвоведению, ботанике, истории и таджикскому языку и направляет в «Фундаментальную библиотеку АН» (БАН) просьбу о выдаче из дублетного фонда литературы по спискам.

9 апреля его просьбу, оставшуюся без ответа, повторяет Комиссия по базам АН СССР, запрашивая из дублетного фонда БАН «всю имеющуюся литературу по ботанике, геологии и почвоведению Бухары, Памира и Ферганской области, отчеты и материалы геологических и почвоведческих экспедиций с приложенными картами» и более 20 справочников по микробиологии, фитопатологии, бактериологии и болезни растений издания 1922-1931 гг. ${ }^{11}$ Только в середине июня из БАН приходит ответ: «За неимением перечисленных в списке книг список выполнен быть не может», впрочем, что-нибудь может найтись «после общей разборки дублетного фонда» ${ }^{12}$. Но Б. А. Федченко продолжает борьбу за создание хотя бы небольшой научной библиотеки. Он обращается к непременному секретарю АН СССР с просьбой о бесплатном получении в издательстве АН 6 экземпляров книг по ботанике и, будучи в июне в командировке в Ленинграде, закупает литературу на 1000 рублей, составляет список из 25 названий советских журналов, в том числе «Успехи современной биологии», «Бюллетень МОИП», «Советский каучук», «Хлопководство», «Марксистско-ленинское естествознание» и других, которые должны быть непременно выписаны на 1933 год. Между прочим, в отчете о работе базы за май - июль 1932 г. должности библиотекаря нет. Нет и помещения для базы и библиотеки, сотрудники работают в своих квартирах, выполняя научные работы по договорам для различных организаций Таджикистана. В конце октября для проверки работы базы из Ленинграда приезжает высокая комиссия, которая 03.11.1932 г.

Архив Российской академии наук. Ф. 188. Оп. 1 (19311935). Д. 22. Л. 44, 67, 71. Переписка Президиума АН СССР с Комиссией по базам АН СССР об организации Базы АН СССР в Сталинабаде, план работ, смета расходов.

Архив Российской академии наук. Ф. 188. Оп. 1 (1931-1935). Д. 22. Л. 168. Переписка Президиума АН СССР с Комиссией по базам АН СССР об организации Базы АН СССР в Сталинабаде, план работ, смета расходов. 


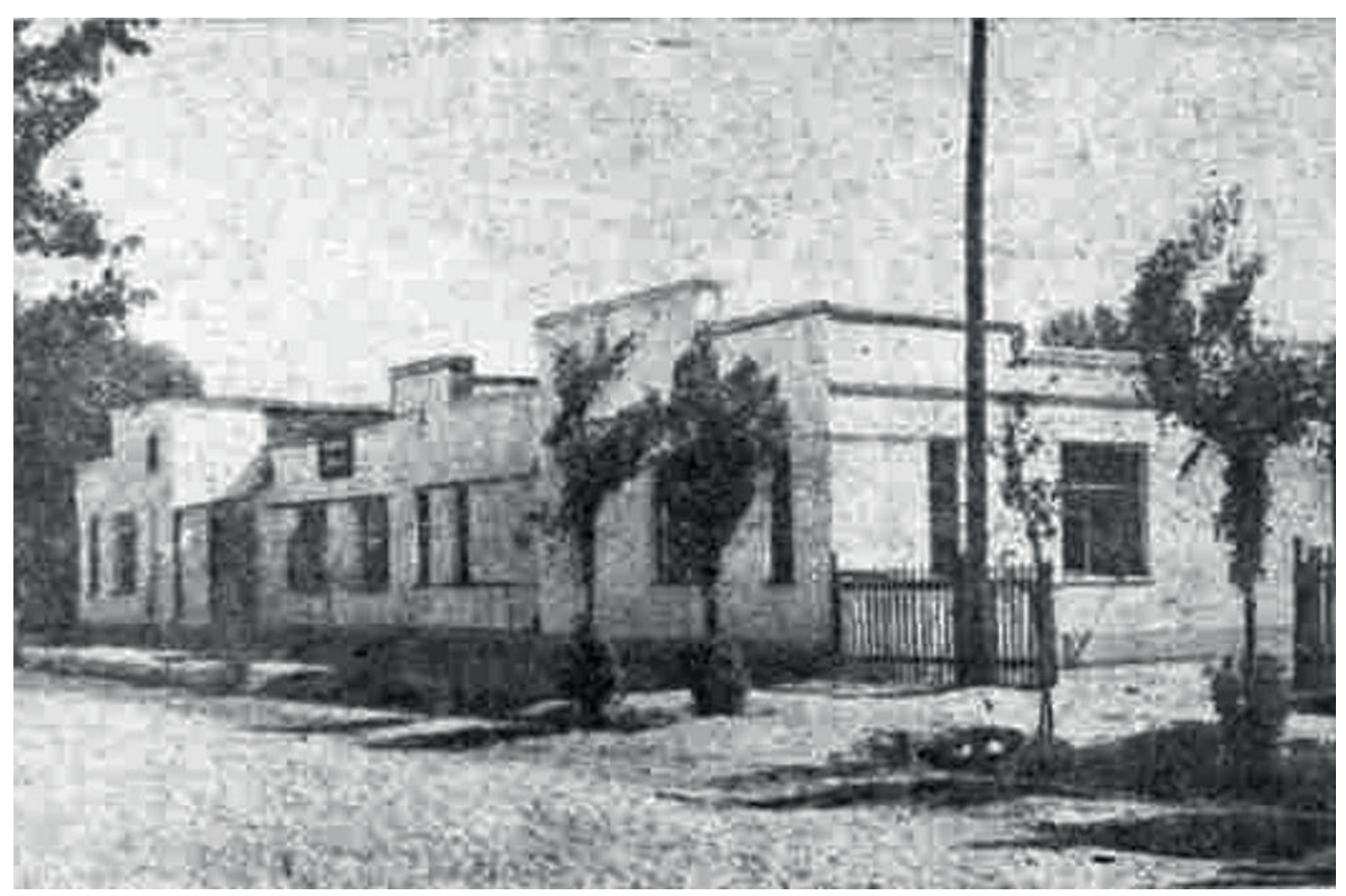

Puс. 7. Геологическая станция Таджикской базы АН СССР (середина 1930-х гг.) Источник: http://khaydarkan.su/arhivy_foto/Kniga_Fedorovskogo/pic/20.htm

постановляет: «Сейчас же начать организацию специальной научной библиотеки (и музея), для чего выделить нужные кредиты и дать соответствующее помещение. Попросить Академию наук произвести отборку книг из своих институтов и дублетного фонда БАН и дублетных материалов институтов и музеев» ${ }^{13}$. Библиотека была организована, библиотекарем назначена Юзефа Руфиновна Мокиевская из Сектора сети специальных библиотек в Москве, и в 1934 г. фонд библиотеки уже составил 4000 библиотечных единиц.

Постановление об организации комплексных научно-исследовательских баз Академии наук СССР в Свердловске было принято Советом народных комиссаров (СНК) в январе 1932 г. с оговоркой «без ассигнования дополнительных средств...»это означало, что финансирование всех работ по созданию академических научных учреждений должны были взять на себя АН СССР и местные административные органы. В июне 1932 г. состоялась первая выездная сессия АН СССР на Урал, в которой приняли участие виднейшие ученые и руководство АН СССР. Впоследствии в отчете о деятельности Комитета филиалов и баз было отмечено: «Решающим моментом в деле децентрализации научной деятельности Всесоюзной

13 Архив Российской академии наук. Ф. 188. Оп. (1931-1935). Д. 22. Л. 316. Переписка Президиума АН СССР с Комиссией по базам АН СССР об организации Базы АН СССР в Сталинабаде, план работ, смета расходов.
Академии наук является первая выездная сессия на Урал и в Новосибирск. Эта сессия за все время существования Академии наук положила начало сближению науки с промышленностью. Вторым шагом Академии наук в децентрализации ее деятельности является организация филиалов и баз на местах» ${ }^{14}$. Научно-исследовательская работа началась в Уральском филиале (УФ) АН СССР в апреле 1933 г. Одновременно перед проектирующими организациями была поставлена задача «создать памятник нашей великой эпохи <...> с весны 1935 года должно начаться строительство собственных зданий (для УФАН), первую очередь которых намечено закончить в 1937 году». Но острая нехватка квалифицированных кадров и финансирования заставили Академию наук изменить первоначальный план развития научных институтов на Урале. Редакционная статья в газете «За социалистическую науку» горько констатировала: «Уральские местные органы не создали для Уральского филиала никакой базы. Начатый на пустом месте Уральский филиал не стал центром научно-исследовательской работы, и Президиум АН вынес решение о свертывании работы институтов до постройки специализированных помещений, ограничившись до этого времени выездом научных бригад, консультациями, проведением выездных сессий УФ АН,

\footnotetext{
Архив Российской академии наук. Ф. 188. Оп. 1 (19311935). Д. 17. Отчет о деятельности филиалов и баз АН СССР за время с 1932 по 1934 год. Л. 2.
} 
экспедиционной работой и наблюдением за постройкой зданий. Вот какое важное значение имеет поддержка и помощь местных организаций для нормального развития филиала» ${ }^{15}$. Статья призывала к реорганизации Комиссии по базам в специальный орган при Президиуме Академии наук, где были бы сосредоточены все функции и вся ответственность за работу филиалов и баз, их снабжение оборудованием и специалистами, научно-издательскую деятельность. В 1935 г. такая комиссия была создана, и в результате ее работы УФ АН СССР в Свердловске в 1938 г. имел две библиотеки (в 1939 г. они были объединены в одну) (рис. 8) с суммарным фондом 13889 библиотечных единиц - в это число входили отечественные и иностранные книги и журналы, а также фотокопии. Имевшаяся литература была очень востребована. Обращаемость фонда составляла 1,85, что являлось очень высоким показателем. Это обеспечивалось главным образом за счет чтения литературы по физике (5976 изданий), физической химии и технике (4522 издания). В 1939 г. выдача составила 8872 издания на абонементе и 18990 - в читальном зале.

Успешное развитие Дальневосточного филиала (ДВФ) АН СССР было обусловлено не только заботой и покровительством видного ученого, вице-президента АН СССР В. Л. Комарова, но и тем, что формировался филиал на базе Дальневосточного краевого научноисследовательского института и Горно-таежной станции. Уже в 1934 г. в состав ДВФ АН входил Химический институт, 5 биологических секторов, кабинет по изучению народов, Комиссия экспедиционных исследований, Горно-таежная и Сейсмическая станции. В этом же году, получив ассигнования в размере 1 млн рублей, руководство ДВФ АН СССР развернуло работы по созданию Морской станции и Геологического сектора, который сформировался на базе Камчатской и Амурской экспедиций. В структуре ДВФ АН СССР было также научное издательство и библиотека, основу которой составил 10-тысячный фонд библиотек Дальневосточного государственного университета и Дальневосточного научно-исследовательского института. В 1934 г. ее фонд составлял уже 25000 томов и она была связана с 300 советскими и 250 зарубежными организациями.

При создании филиалов и баз АН СССР в 30-х годах XX в. некоторые периферийные научные учреждения просто меняли юрисдикцию - переходили под эгиду Академии наук СССР. Так, в 1934 г. Хибинская горная станция, основанная в 1930 г. по инициативе академика А. Е. Ферсмана, была преобразована в Кольскую базу им. С. М. Кирова (рис. 9). Личная библиотека академика, переданная базе в 1932 г., стала основой научной библиотеки нового учреждения АН. Библиотека к 1941 г. имела 200 книг, 5748 отечественных и 2592 иностранных журнала и вела обмен со всеми филиалами АН СССР,

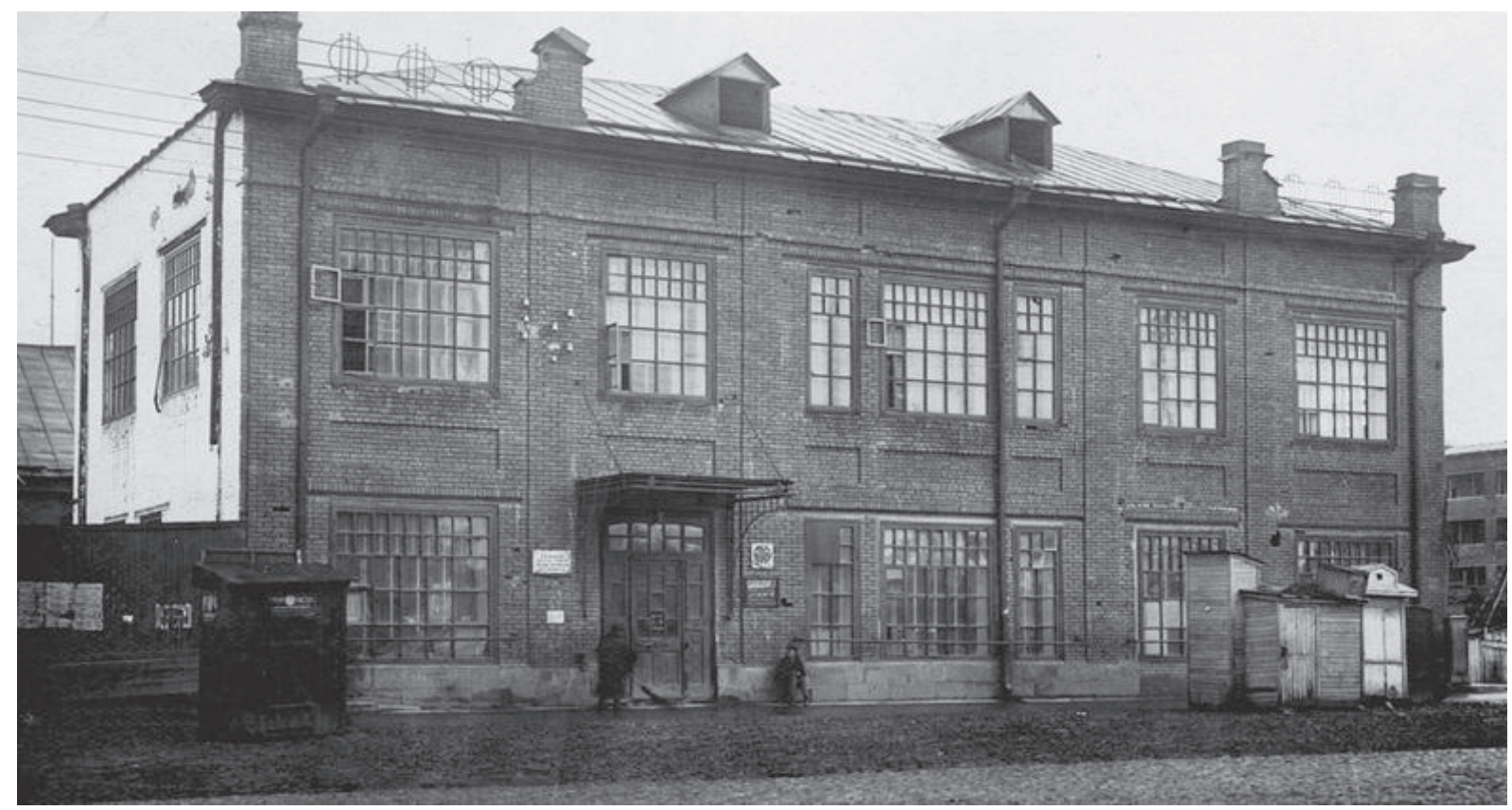

Pис. 8. Библиотека Уральского филиала АН СССР. Свердловск (1930-е гг.) Источник: Санкт-Петербургский филиал Архива Российской академии наук. Ф. 191. Оп. 1. Д. 26. Л. 68.

15 Архив Российской академии наук. Ф. 188. Оп. 1 (19311942). Д. 38. Л. 2. Статьи о работе филиалов и баз для газеты «За социалистическую науку». 


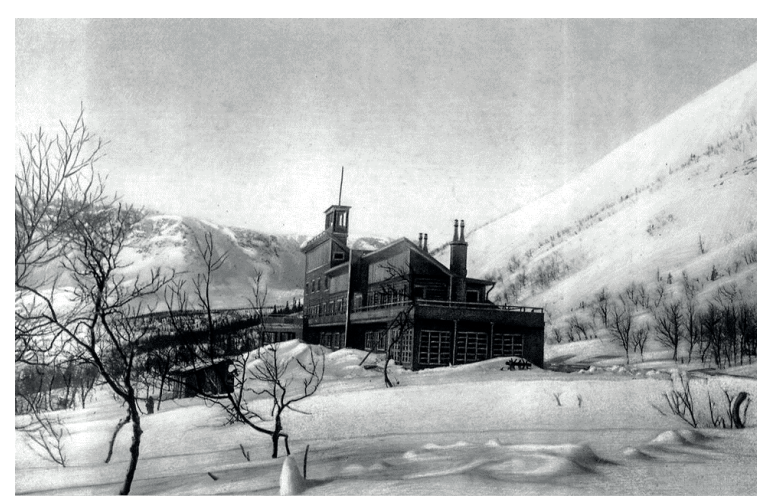

Puс. 9. Кольская база АН СССР им. С. М. Кирова

с библиотекой Московского и Саратовского университетов и некоторыми другими.

В 1935 г. академическим учреждением стала функционировавшая с 1928 г. Лимнологическая станция в поселке Листвянка на Байкале (рис. 10). При станции работала библиотека, которая в 1940 г. имела фонд 2942 библиотечных единицы, но библиотекаря не было; литературу выдавал один из сотрудников, однако учет работы он не вел.

Как же велось формирование фондов этих новых академических библиотек, как осуществлялось материальное и методическое обеспечение?

\section{Комплектование библиотек филиалов и баз АН СССР}

С самого начала формирование и пополнение фондов новых академических библиотек было возложено на Библиотеку Академии наук в Ленинграде. Из имеющихся в БАН дублетных и неразобранных фондов отечественной и иностранной литературы (в 1933 г. - 750000 библиотечных единиц) была выделена часть монографий и периодических изданий и распределена между библиотеками созданных академических учреждений [4, с. 93-94].

Источниками комплектования библиотек баз и филиалов по новой литературе являлись советские издательства, а по литературе до 1925 г. - дублетные фонды БАН и ее филиалов, Ленинградского отделения Центральной книжной палаты ${ }^{16}$, дублетные фонды различных учреждений и частные библиотеки, которые предлагались к продаже ${ }^{17}$. Комплектование текущей иностранной литературой всех академических

\footnotetext{
В 1938 г. Ленинградское отделение Книжной палать было ликвидировано. С этого времени распределение второго обязательного экземпляра стал осуществлять Сектор сети специальных библиотек в составе Фундаментальной библиотеки по общественным наукам АН СССР.

Санкт-Петербургский филиал Архива Российской академии наук. Ф. 158. Оп. 3 (1933). Д. 20. Л. 45. Отчеты, записки и переписка по комплектованию библиотек баз, филиалов и станций АН СССР.
}

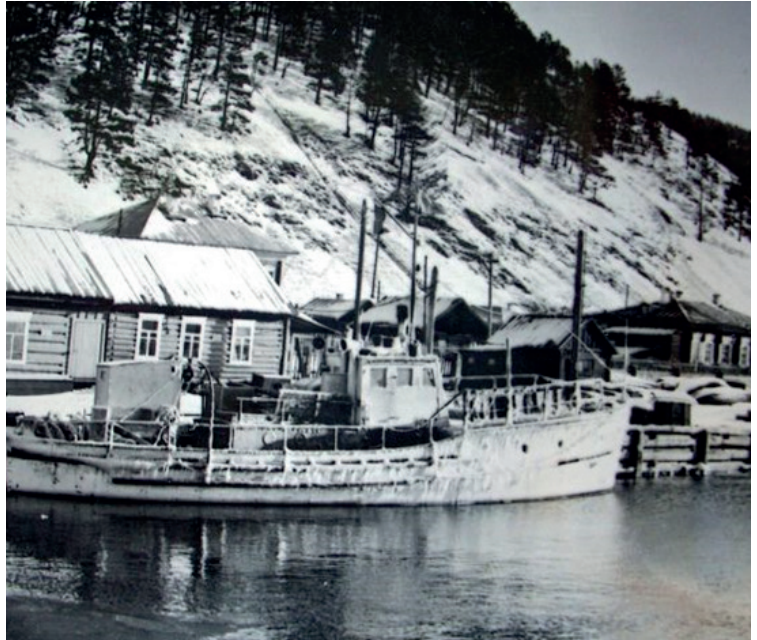

Pис. 10. Лимнологическая станция в поселке Листвянка на Байкале.

Источник: http://www.magicbaikal.ru/history/ images/baikal-vereschagin-2.jpg

библиотек, в том числе библиотек филиалов и баз, осуществляла только БАН в Ленинграде за счет валютных ассигнований АН СССР: «БАН ведет комплектование иностранной научной литературой библиотек АН на периферии, обслуживает их по коллективному абонементу» ${ }^{18}$. «Перечень иностранных изданий, заказанных для филиалов и баз на 1937 год, занимает 30 машинописных листов» 19

Заявки ученых из филиалов и баз на научную литературу сначала направлялись в Москву, из Москвы - в Ленинград, где суммировались в отделе иностранного комплектования БАН, затем передавались на заключение экспертной комиссии. После рассмотрения заявок в комиссии, состоявшей из академиков и членов-корреспондентов по различным наукам, заказы передавались на утверждение непременного секретаря АН СССР ${ }^{20}$, с визой которого они и поступали в Книжный отдел при Президиуме АН СССР, а из него - в «Международную книгу». Несмотря на сложную бюрократическую процедуру и постоянное урезание лимитов, иностранная литература поступала даже в самые отдаленные библиотеки.

В таблице 1 приведены данные о распределении по филиалам и базам валюты на иностранные монографии на 1937 год. При этом в резерве Президиума АН СССР было оставлено 50000 рублей на тот случай, если кому-то из академиков срочно понадобится какая-то монография из-за рубежа.

\footnotetext{
Санкт-Петербургский филиал Архива Российской академии наук. Ф. 158. Оп. 3 (1936). Д. 83. Л. 30. Материалы по проектированию здания БАН в Москве. 19 Архив Российской академии наук. Ф. 188. Оп.1 (19311942). Д. 378. Л.1-30. Списки иностранной литературы, выписанной для филиалов и баз на 1937 год.

20 Впоследствии председателя Библиотечной комиссии.
} 


\section{Распределение иностранной валюты по филиалам и базам АН СССР на иностранные} монографии на 1937 г.

\begin{tabular}{|l|c|}
\multicolumn{1}{|c|}{ Наименование филиала или базы } & $\begin{array}{c}\text { Размеры финанси- } \\
\text { рования / руб. }\end{array}$ \\
\hline Кольская база (КОБ) & 2500 \\
\hline Северная база (Коми) & 2500 \\
\hline Уральский филиал (УФАН) с Ильменским заповедником & 3750 \\
\hline Грузинский филиал (ГрузФАН) & 3750 \\
\hline Институт языка и материальной культуры (ИЯИМК) Грузинского филиала & 1250 \\
\hline Армянский филиал (АрмФАН) & 3750 \\
\hline Казахский филиал (КазФАН) & 3750 \\
\hline Дальневосточный филиал (ДВФАН) & 3750 \\
\hline Таджикская база & 2000 \\
\hline ИТОГО & 30750 \\
\hline
\end{tabular}

Источник: Научный Архив БЕН РАН. Оп. 2. Д. 2. Л. 1, 6-31

Количество иностранных книг в библиотеках филиалов и баз АН СССР редко превышало 1000 библиотечных единиц. Для заказа на местах иностранного издания из-за границы требовалась, во-первых, информация о нем, а во-вторых, тщательная библиографическая выверка, что было практически невыполнимо ввиду отсутствия на местах библиографических справочных изданий. Периодических изданий для баз и филиалов АН СССР по разным тематическим направлениям исследований в 1937 г. было заказано на 60310 рублей.

Таблица 2 дает представление о географии филиалов и баз АН СССР, тематическом разнообразии проводимых научных исследований и финансировании на зарубежное комплектование.

Десять библиотек естественно-научного профиля, помимо комплектования через БАН, пополняли свои фонды путем международного и внутрисоюзного книгообмена. В 30-е годы XX в. в СССР уже существовала монополия на закупку иностранных изданий за рубежом, но монополии на ведение международного книгообмена еще не было. Поэтому библиотеки академических институтов, созданные на базе уже имевшихся научных учреждений, интенсивно обменивались литературой с зарубежными партнерами. В основном это касалось научных трудов и других изданий самого института, но получение по книгообмену литературы для заполнения лакун не носило систематический характер, несмотря на большое число партнеров. Даже библиотека Байкальской лимнологической станции в Листвянке, где не было библиотечного работника, вела внутрисоюзный и международный книгообмен. Представление о масштабах международного и внутрисоюзного книгообмена в новых академических библиотеках дает таблица 3. Впрочем, некоторые библиотеки не отличали книгообмен от МБА.

В отдельных случаях вопрос о комплектовании библиотеки филиала или базы рассматривался на заседании Президиума АН СССР. Так, например, решение о выделении литературы в организуемые библиотеки автономной области Коми (Северная база) было принято 25 октября 1934 г.: «Поручить Библиотеке АН представить свои соображения о том, что можно выдать из дублетных фондов Библиотеки в организуемые библиотеки в автономной области Коми; Издательству АН запросить от Коми список необходимой им литературы из академических изданий» ${ }^{21}$. В феврале 1938 г. на распорядительном заседании Президиума АН СССР обсуждался вопрос об организации специальной библиотеки при Мурманской биостанции и о разрешении БАН передать дублетные экземпляры в библиотеку Мурманской биостанции. «Постановили: разрешить Мурманской биологической станции иметь специальную научную библиотеку при станции. Включить библиотеку Мурманской биологической станции в общую сеть специальных библиотек Академии наук. Разрешить БАН передать из дублетного фонда бывшей Полярной комиссии в библиотеку Мурманской биологической станции (рис. 11) литературу по специальности» ${ }^{22}$.

После отделения в конце 1939 г. Сектора сети специальных библиотек от Фундаментальной библиотеки по общественным наукам и получения

21 Архив Российской академии наук. Ф. 2. Оп. 6. Д. 1. Л. 52, 57, 58. Протоколы (№ 21) заседаний Президиума Академии Наук СССР за 1934 год №№ 16-27.

22 Архив Российской академии наук. Ф. 2. Оп. 6. Д. 11. л. 160. Протоколы (№ 8) заседаний Президиума АН СССР за 1938 год, параграф 10. 


\section{Распределение иностранной валюты на иностранные журналы по тематикам для библиотек филиалов и баз АН СССР на 1937 год}

\begin{tabular}{|c|c|c|c|c|}
\hline $\begin{array}{c}\text { Наименование } \\
\text { филиала или базы }\end{array}$ & $\begin{array}{l}\text { Количество } \\
\text { названий }\end{array}$ & $\begin{array}{l}\text { Сумма, } \\
\text { руб. }\end{array}$ & Языки & Тематика \\
\hline $\begin{array}{l}\text { Азербайджанский } \\
\text { филиал }\end{array}$ & 44 & - & $\begin{array}{l}\text { Англ., фр., } \\
\text { нем. }\end{array}$ & $\begin{array}{l}\text { Ботаника, биохимия, геология, промышленная } \\
\text { химия, минералогия, паразитология, инженерное } \\
\text { дело, религиоведение }\end{array}$ \\
\hline Армянский филиал & 60 & 6088 & $\begin{array}{l}\text { Англ., фр., } \\
\text { нем. }\end{array}$ & Ботаника, химия, геология, генетика \\
\hline $\begin{array}{l}\text { Химический институт } \\
\text { ГрузФАН }\end{array}$ & 24 & 3080 & $\begin{array}{l}\text { Англ., фр., } \\
\text { нем. }\end{array}$ & $\begin{array}{l}\text { Металлургия, металлообработка, химия, } \\
\text { электрохимия }\end{array}$ \\
\hline $\begin{array}{l}\text { Математический инсти- } \\
\text { тут ГрузФАН }\end{array}$ & 26 & - & $\begin{array}{l}\text { Нем, фр., } \\
\text { англ., итал. }\end{array}$ & Математика, теоретическая и прикладная \\
\hline $\begin{array}{l}\text { Геофизический институт } \\
\text { ГрузФАН }\end{array}$ & 18 & 1286 & $\begin{array}{l}\text { Англ., фр., } \\
\text { нем. }\end{array}$ & $\begin{array}{l}\text { Геофизика, сейсмология, инженерное дело, а также } \\
\text { японский астрономический журнал на англ. языке }\end{array}$ \\
\hline $\begin{array}{l}\text { Ботанический институт } \\
\text { ГрузФАН, } \\
\text { Зоологический сектор }\end{array}$ & $\begin{array}{l}13 \\
7\end{array}$ & $\begin{array}{l}1488 \\
508\end{array}$ & $\begin{array}{l}\text { Англ., фр., } \\
\text { нем. }\end{array}$ & Ботаника, зоология, генетика, экология \\
\hline $\begin{array}{l}\text { Абастуманская } \\
\text { обсерватория }\end{array}$ & 48 & 3870 & $\begin{array}{l}\text { Англ., фр., } \\
\text { нем. }\end{array}$ & Астрономия, физика, математика \\
\hline $\begin{array}{l}\text { Институт истории и ма- } \\
\text { териальной культуры }\end{array}$ & 73 & 3830 & $\begin{array}{l}\text { Англ., фр., } \\
\text { нем. }\end{array}$ & $\begin{array}{l}\text { Фонетика, семитские языки, ориенталистика, } \\
\text { ассирология }\end{array}$ \\
\hline Казахский филиал & 49 & - & $\begin{array}{l}\text { Англ., фр., } \\
\text { нем. }\end{array}$ & $\begin{array}{l}\text { Археология, ботаника, биология, экология, исто- } \\
\text { рия, флора, сельское хозяйство, млекопитающие, } \\
\text { химия, паразитология }\end{array}$ \\
\hline Кольская база & 50 & 5000 & $\begin{array}{l}\text { Англ., фр., } \\
\text { нем., швед. }\end{array}$ & $\begin{array}{l}\text { Ботаника, минералогия, геология, физиология } \\
\text { растений, химия, экология, география }\end{array}$ \\
\hline Северная база & 26 & 2410 & $\begin{array}{l}\text { Англ., фр., } \\
\text { нем. }\end{array}$ & $\begin{array}{l}\text { Зоология, рыбное хозяйство, ботаника морские } \\
\text { млекопитающие, орнитология, география }\end{array}$ \\
\hline Таджикская база & 78 & 4000 & $\begin{array}{l}\text { Англ., фр., } \\
\text { нем. }\end{array}$ & $\begin{array}{l}\text { Астрономия, астрофизика, ботаника, востоковеде- } \\
\text { ние, геология, сельское хозяйство, энтомология, } \\
\text { зоология }\end{array}$ \\
\hline $\begin{array}{l}\text { Уральский филиал, } \\
\text { Ильменский заповедник }\end{array}$ & $\begin{array}{c}52 \\
8\end{array}$ & $\begin{array}{l}5244 \\
1075\end{array}$ & $\begin{array}{l}\text { Англ., фр., } \\
\text { нем. }\end{array}$ & $\begin{array}{l}\text { Химия, физика, металлургия } \\
\text { Минералогия, химия, аналитическая химия, } \\
\text { природа }\end{array}$ \\
\hline
\end{tabular}

Источник: Научный Архив БЕН РАН. ОП. 2. Д. 2. Л. 17-25

таблица 3

Сведения о книгообмене библиотек филиалов и баз АН СССР в 1939 г.

\begin{tabular}{|l|c|c|c|}
\hline \multicolumn{1}{|c|}{ Название учреждения } & $\begin{array}{c}\text { Количество } \\
\text { партнеров в СССР }\end{array}$ & $\begin{array}{c}\text { Количество } \\
\text { зарубежных } \\
\text { партнеров }\end{array}$ & Примечание \\
\hline $\begin{array}{l}\text { Фундаментальная библиотека } \\
\text { АзФАН }\end{array}$ & 130 & - & $\begin{array}{c}\text { Без деления на совет- } \\
\text { ские и зарубежные }\end{array}$ \\
\hline Ботанический институт АзФАН & 114 & 229 & - \\
\hline Геологический институт АзФАН & 7 & - & - \\
\hline Зоологический институт АзФАН & 70 & 30 & - \\
\hline Лимнологическая станция & $\begin{array}{c}\text { Ведется в незначитель- } \\
\text { ном количестве }\end{array}$ & - & - \\
\hline
\end{tabular}


Окончание табл. 3

\begin{tabular}{|c|c|c|c|}
\hline Название учреждения & $\begin{array}{c}\text { Количество } \\
\text { партнеров в СССР }\end{array}$ & $\begin{array}{c}\text { Количество } \\
\text { зарубежных } \\
\text { партнеров }\end{array}$ & Примечание \\
\hline Химический институт ГрузФАН & 35 НИУ и 11 библиотек & - & - \\
\hline Геофизический институт ГрузФАН & 72 & 190 & - \\
\hline $\begin{array}{l}\text { Тбилисский Ботанический } \\
\text { институт }\end{array}$ & Ведется & - & Количество не указано \\
\hline $\begin{array}{l}\text { Библиотека Абастуманской } \\
\text { обсерватории }\end{array}$ & 250 & - & $\begin{array}{l}\text { Без деления на совет- } \\
\text { ские и зарубежные }\end{array}$ \\
\hline Геологический институт АрмФАН & $\begin{array}{l}\text { Ведется в незначитель- } \\
\text { ном количестве }\end{array}$ & - & - \\
\hline Кольская база им. С. М. Кирова & $\begin{array}{c}\text { Ведется со всеми филиа- } \\
\text { лами и базами АН, МГУ, } \\
\text { СгУ Саратов. }\end{array}$ & - & - \\
\hline $\begin{array}{l}\text { Объединенная библиотека } \\
\text { Уральского филиала }\end{array}$ & Данных нет & - & - \\
\hline
\end{tabular}

Источник: Научный Архив БЕН РАН. Оп. 2. Д. 2. Л. 5-31.

им финансовой самостоятельности Сектору передается функция обслуживания библиотек филиалов и баз. По указанию БАН - головной библиотеки АН СССР - в конце 1939 г. Сектором сети была проведена централизованная подписка на отечественные и иностранные периодические издания для иногородних академических библиотек естественно-научного профиля. В таблице 4 приведены данные по подписке на 1940 г.

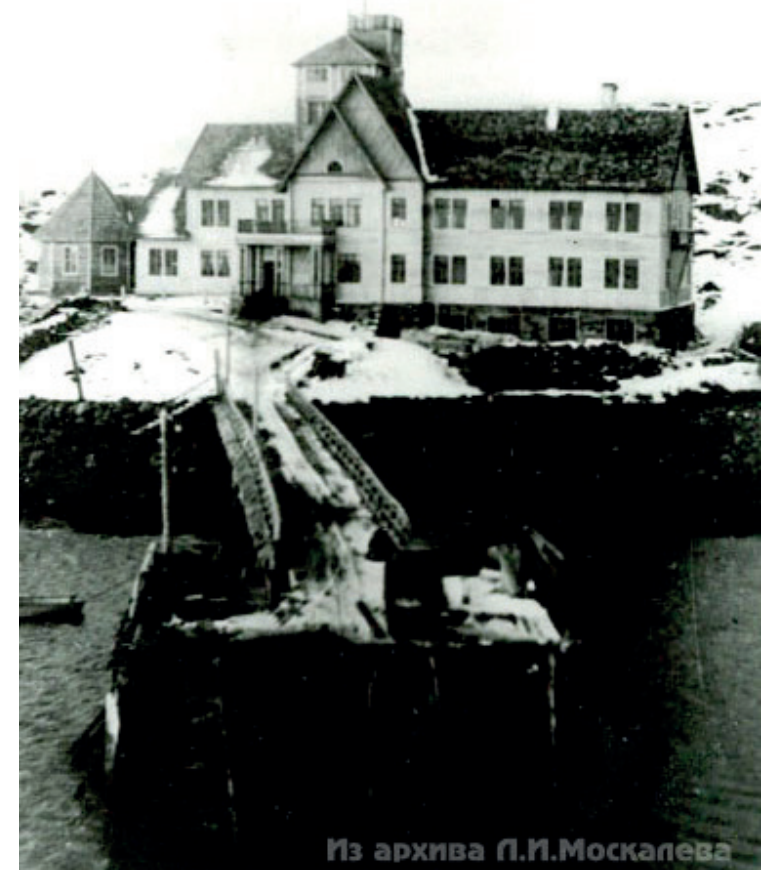

Puc. 11. Мурманская биологическая станция «Дальние Зеленцы».

Источник: https://www.littorina.info/zelenci/ stancia/fotoarh/09.005.jpg
По итогам успешно проведенной Сектором сети специальных библиотек подписки Комитет по заведованию филиалами и базами направляет в Библиотечную комиссию АН СССР докладную записку по вопросам комплектования библиотек периферийных учреждений АН СССР. Библиотечная комиссия перенаправляет эту записку в главную библиотеку всех академических учреждений. Поступивший 11 февраля 1940 г. ответ из БАН в Комитет по заведованию филиалами и базами АН СССР приведен на рисунке 12.

С укреплением к 1940 г. Сектора сети специальных библиотек центр по руководству и обслуживанию библиотек филиалов и баз Академии наук СССР фактически переместился из Ленинграда в Москву, где была создана группа сотрудников, ведавшая только этими библиотеками.

22 февраля 1940 г. заведующий Сектором сети специальных библиотек В. В. Морозкин издает Приказ № 11: «Ст. библиотекаря Ю. Р. Мокиевскую назначить зав. Группой по обслуживанию библиотек баз и филиалов. Тов. Мокиевской поручить в 5-дневный срок представить план работы. О. М. Федоровской, Г. В. Закржевскому и Ю. Р. Мокиевской поручается в 5-дневный срок разработать Положение, определяющее порядок комплектования и расчетов с библиотеками баз и филиалов». Подписано: Зав. сетью В. Морозкин ${ }^{23}$.

При передаче Сектору сети специальных библиотек функции обслуживания библиотек баз и филиалов руководство БАН предписало провести их паспортизацию в соответствии с анкетой, разработанной БАН для своих ленинградских филиалов (рис. 13). В конце марта 1940 г. 100 экземпля-

23 Научный Архив БЕН РАН. Оп. 4 дел по личному составу. Д. 1. Л. 14 
Данные о подписке библиотек филиалов и баз АН СССР на 1940 г.

\begin{tabular}{|l|c|c|}
\hline \multicolumn{1}{|c|}{ Наименование филиала } & $\begin{array}{c}\text { Отечественные } \\
\text { журналы }\end{array}$ & $\begin{array}{c}\text { Иностранные } \\
\text { журналы }\end{array}$ \\
\hline Фундаментальная библиотека Азербайджанского филиала АН СССР & 164 & 70 \\
\hline Библиотека Химического института Грузинского филиала АН СССР & 60 & 11 \\
\hline Библиотека Ботанического института в Тбилиси & 15 & 34 \\
\hline Библиотека Абастуманской астрофизической обсерватории в Грузии & 43 \\
\hline Библиотека Геофизического института Грузинского филиала АН СССР & 146 \\
\hline Фундаментальная библиотека Казахского филиала АН СССР & 60 & 176 \\
\hline Библиотека Кольской базы АН СССР & 75 \\
\hline Библиотека Уральского филиала АН СССР & 15 \\
\hline Библиотека Байкальской лимнологической станции & 49 \\
\hline
\end{tabular}

Источник: Научный Архив БЕН РАН. Оп. 2. Д. 2. Л. 3, 4.

ров этой анкеты были отпечатаны в типографии БАН и разосланы на места от имени Библиотечной комиссии при Президиуме АН СССР за подписью ее председателя академика А. А. Борисяка. Заведующим библиотеками надлежало представить сведения о профиле библиотеки, количестве и составе фонда, о состоянии каталогов и картотек, книгообмене, количестве посещений, книговыдаче, справочной работе, источниках финансирования и, наконец, описать библиотечные помещения по состоянию на 1 января 1940 г.

В течение первой половины 1940 г. в Сектор сети специальных библиотек поступило 17 анкетпаспортов из библиотек филиалов АН СССР в Азербайджане, Грузии, Армении и Казахстане, а также Кольской базы им. С. М. Кирова, Лимнологической станции на Байкале и 2 научных библиотек Уральского филиала АН СССР.

Анализ результатов анкетирования позволил обобщить данные о новых библиотеках, выявить объем фондов, количество читателей, тематические, финансовые, материальные и кадровые потребности. В таблице 5 представлены некоторые данные о состоянии периферийных библиотек и их работе с читателями в 1939 г.

Данные анкетирования показали, что большинство библиотек обслуживали только сотрудников своих научных организаций, число которых не достигало и сотни.

В ряде библиотек даже не считали нужным учитывать посещаемость. Для руководителей институтов состояние библиотеки не являлось приоритетным, она не всегда имела собственное помещение, или оно было настолько мало, что не полностью вмещало весь фонд. Отдельные читальные залы имелись только в Фундаментальной библиотеке
Азербайджанского филиала АН СССР и в библиотеке Химического института Грузинского филиала АН СССР. Кое-где читатели занимались то в «красном уголке», то в книгохранении. Книговыдача тоже была невелика, но все же была больше в тех библиотеках, которыми пользовались еще и студенты вузов. Слабая активность в использовании возможностей МБА объяснялась не только пассивностью библиотекарей. Библиотеки, находившиеся на балансе института, иногда просто не имели денег на конверты, марки и отправку бандеролей. Во всяком случае, это постоянно отмечали сотрудники Сектора сети специальных библиотек. Да и срок выполнения заказов по МБА не всегда устраивал читателей. Библиотека Уральского филиала жаловалась на то, что «посланные заявки и запросы (в БАН) долгое время остаются без ответа» ${ }^{24}$. К тому же с 1938 г. БАН в Ленинграде принимала заказы по МБА только на своих бланках, которые бесплатно не выдавались. Их надо было заказывать в Ленинграде и получать наложенным платежом: 100 штук - 3 рубля.

\section{Справочно-библиографическая и методическая работа}

Почти во всех анкетах ответ на вопрос «основные нужды библиотеки», помимо нехватки площадей и финансирования, почти все заведующие указали отсутствие систематического методического руководства и обеспечения библиотечной техникой. Помимо выдачи книг, любая библиотека должна была помогать читателям найти нужное издание, и в этом аспекте работы большое значение имели квалификация и уровень образования библиотечного работника. 

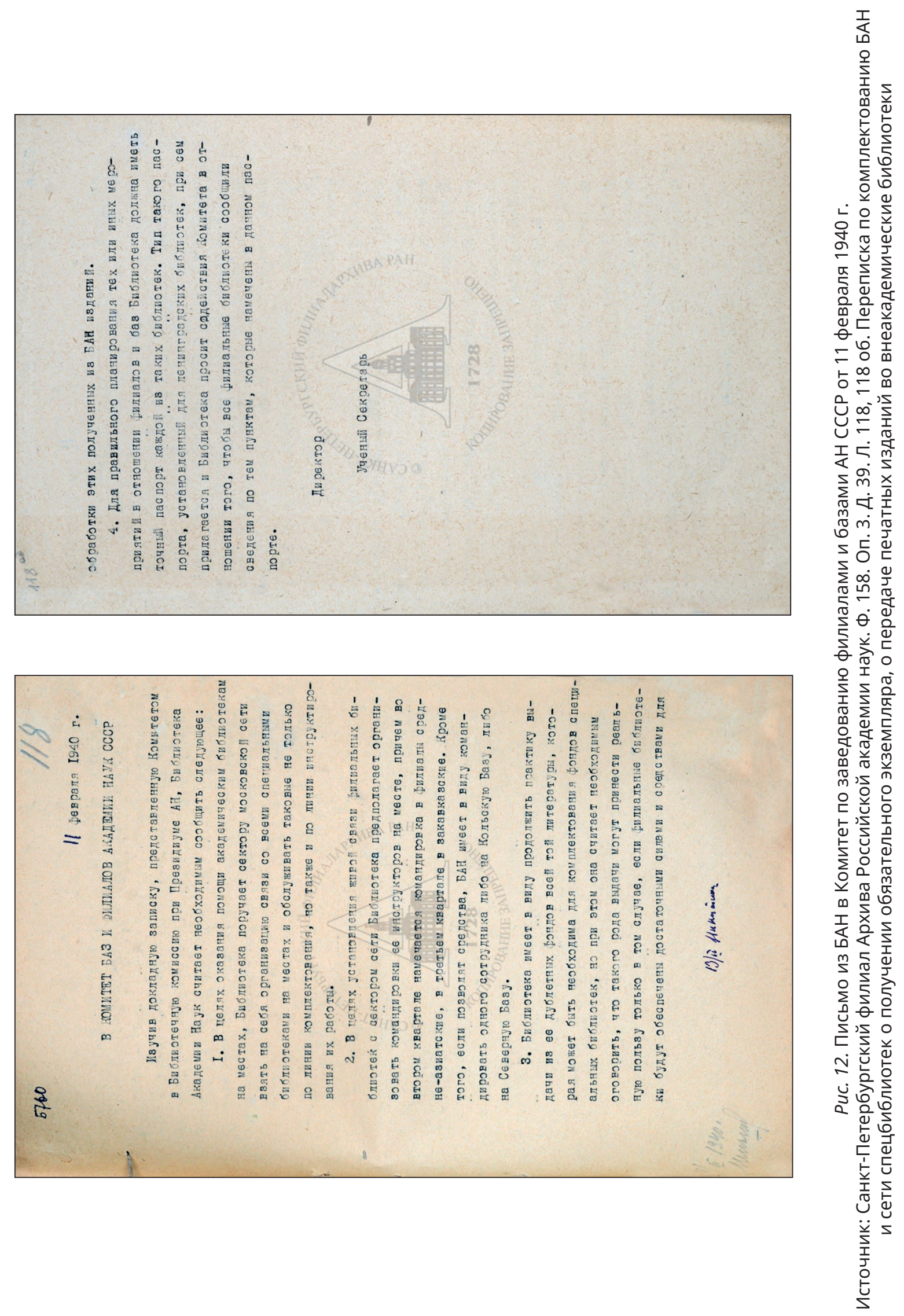

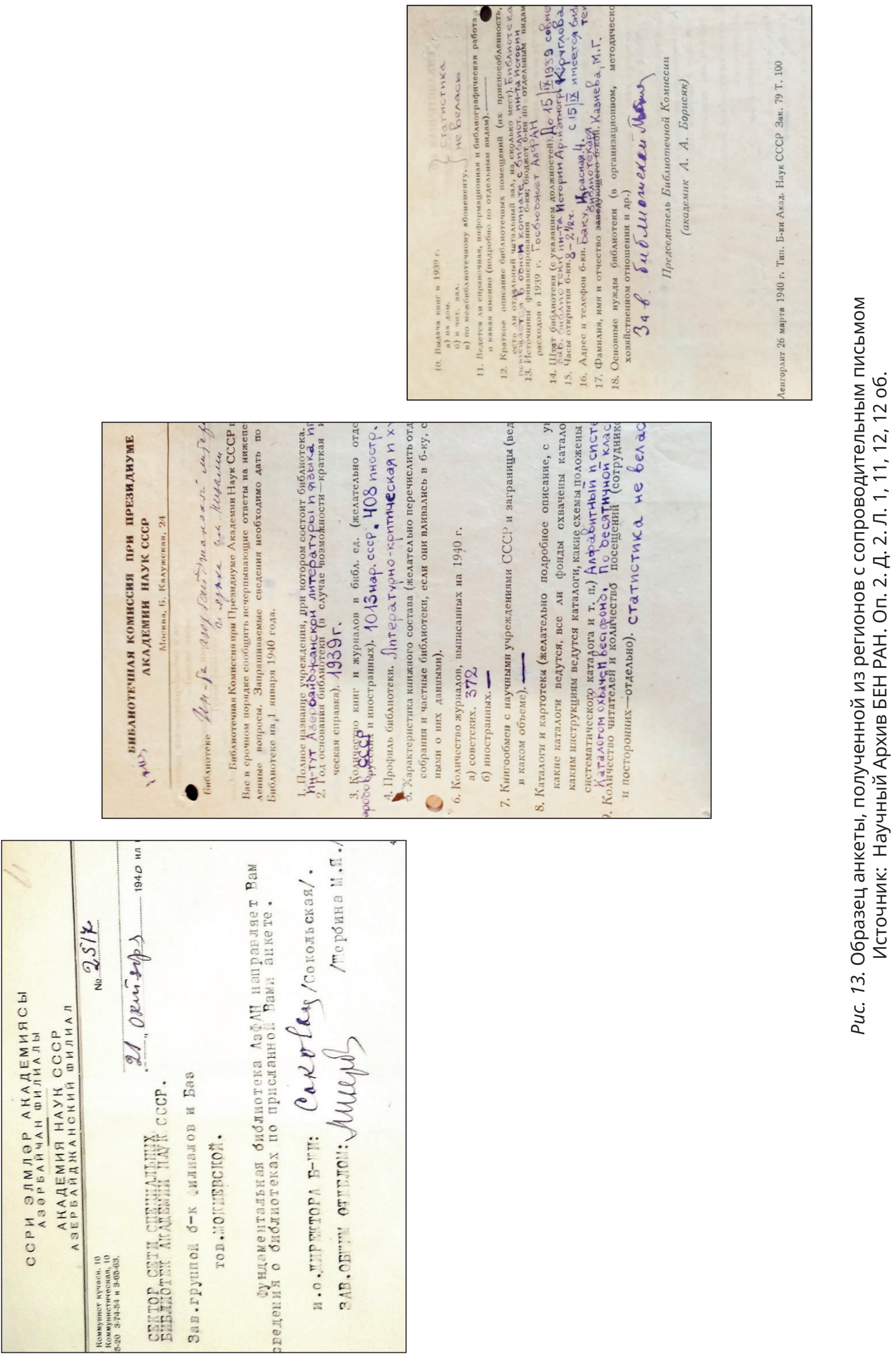
Обобщенные данные анкетирования библиотек

\begin{tabular}{|c|c|c|c|c|c|c|c|}
\hline \multirow{2}{*}{ 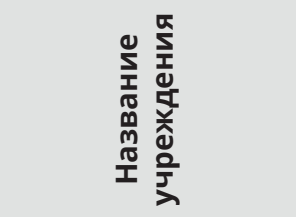 } & \multirow{2}{*}{ 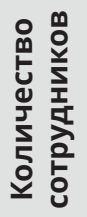 } & \multirow{2}{*}{ 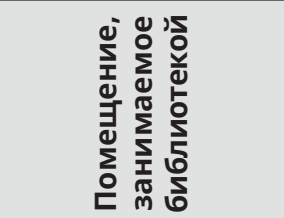 } & \multirow{2}{*}{ 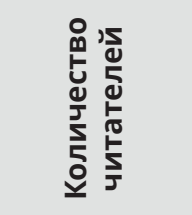 } & \multirow{2}{*}{ 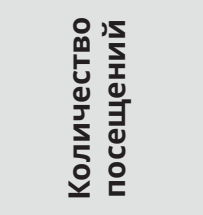 } & \multicolumn{2}{|c|}{ Книговыдача } & \multirow[b]{2}{*}{ МБА } \\
\hline & & & & & $\begin{array}{l}\text { читаль- } \\
\text { ный зал }\end{array}$ & $\begin{array}{c}\text { абоне- } \\
\text { мент }\end{array}$ & \\
\hline $\begin{array}{l}\text { Фундаментальная } \\
\text { библиотека АзФАН }\end{array}$ & 15 & $\begin{array}{c}\text { ч/з на } 40 \\
\text { читателей }\end{array}$ & 500 & 3149 & 1974 & 3064 & 115 \\
\hline $\begin{array}{l}\text { Ботанический } \\
\text { институт АзФАН }\end{array}$ & 1 & $\begin{array}{l}1 \text { комната } 50 \text { м² ч/з } \\
\text { в «красном уголке» }\end{array}$ & $\begin{array}{c}\text { Сотрудники } \\
\text { и студенты } \\
\text { АГУ }\end{array}$ & Учет не велся & 3528 & 6234 & - \\
\hline $\begin{array}{l}\text { Геологический } \\
\text { институт АзФАН }\end{array}$ & 1 & $\begin{array}{c}2 \text { комнаты в пе- } \\
\text { трографической } \\
\text { лаборатории } \\
\text { ч/з нет }\end{array}$ & $\begin{array}{c}48 \\
\text { сотрудников } \\
8 \\
\text { посторонних }\end{array}$ & 550 & - & 935 & 113 \\
\hline $\begin{array}{l}\text { Зоологический } \\
\text { институт АзФАН }\end{array}$ & 1 & $\begin{array}{c}\text { Библиотека рас- } \\
\text { положена в каби- } \\
\text { нете директора, } \\
\text { в канцелярии } \\
\text { и коридоре }\end{array}$ & $\begin{array}{c}\text { Сотрудники } \\
\text { института }\end{array}$ & Учет не велся & - & 2037 & - \\
\hline $\begin{array}{l}\text { Библиотека } \\
\text { Института энцик- } \\
\text { лопедий и словарей } \\
\text { АзФАН }\end{array}$ & 1 & $\begin{array}{c}\text { Книгохранение } \\
\text { и ч/з в } 1 \text { комнате }\end{array}$ & 49 & 546 & 3013 & 791 & 16 \\
\hline $\begin{array}{l}\text { Геологический } \\
\text { институт АрмФАН }\end{array}$ & 1 & $\begin{array}{l}1 \text { комната } \\
\text { ч/з нет }\end{array}$ & 39 & Учет не велся & - & 323 & - \\
\hline $\begin{array}{l}\text { Химический инсти- } \\
\text { тут ГрузФАН }\end{array}$ & 2 & $\begin{array}{c}3 \text { комнаты } \\
81,59 \mathrm{M}^{2} \\
4 / 3-33 \mathrm{M}^{2}\end{array}$ & 81 & $\begin{array}{c}7 \text { 459+190 } \\
\text { посторонних }\end{array}$ & 3555 & 3723 & 181 \\
\hline $\begin{array}{l}\text { Геофизический } \\
\text { институт ГрузФАН }\end{array}$ & 1 & $\begin{array}{c}35 \text { м }^{2} \\
\text { ч/з на } 1 \text { читателя }\end{array}$ & $\begin{array}{c}40 \\
\text { сотрудников } \\
15 \\
\text { посторонних }\end{array}$ & Учет не велся & - & 1101 & 60 \\
\hline $\begin{array}{l}\text { Тбилисский } \\
\text { Ботанический } \\
\text { институт }\end{array}$ & 2 & $\begin{array}{c}\text { 4/3 нет } \\
3 \text { комнаты } 50 \text { м² }^{2}\end{array}$ & 84 & 1324 & 2523 & 1680 & 22 \\
\hline $\begin{array}{l}\text { Библиотека } \\
\text { Абастуманской } \\
\text { обсерватории }\end{array}$ & 1 & $\begin{array}{c}1 \text { комната } \\
60 \text { м }^{2} \\
\text { 4/3 нет }\end{array}$ & 30 & 10-12 в сутки & $\begin{array}{c}\text { Учет } \\
\text { не велся }\end{array}$ & 400 & 20 \\
\hline $\begin{array}{l}\text { Казахстанский } \\
\text { филиал }\end{array}$ & 3 & $\begin{array}{c}\text { 4/з нет } \\
1 \text { комната } \\
37 \mathrm{M}^{2}\end{array}$ & 150 & 1575 в месяц & 9275 & & 105 \\
\hline $\begin{array}{l}\text { Кольская база } \\
\text { им. С. М. Кирова }\end{array}$ & 1 & $\begin{array}{c}\text { 4/з нет } \\
\text { помещение } \\
\text { библиотеки } \\
\text { вмещает только } \\
\text { 40\% фонда }\end{array}$ & 60 & Учет не велся & $\begin{array}{c}591 \\
\text { не вынося } \\
\text { из библио- } \\
\text { теки }\end{array}$ & 1017 & 6 \\
\hline $\begin{array}{l}\text { Лимнологическая } \\
\text { станция на Байкале }\end{array}$ & - & 1 комната, ч/з нет & $\begin{array}{c}\text { Сотрудники } \\
\text { станции }\end{array}$ & Уче & т не велся & & - \\
\hline $\begin{array}{l}\text { Объединенная } \\
\text { библиотека } \\
\text { Уральского филиала }\end{array}$ & 2 & Нет данных & Нет данных & $\begin{array}{c}\text { ч/3 - } 43611 \\
\text { Абонемент - } \\
7032\end{array}$ & 18990 & 8872 & 851 \\
\hline
\end{tabular}

Источник: НаучныЙ Архив БЕН РАН. Оп. 2. Д. 2. Л. 1, 6-31 
Анкетирование показало, что справочнобиблиографическая работа реально велась только в библиотеке Химического института Грузинского филиала АН СССР: «Выдаются читательские устные справки из энциклопедий, отыскиваются нужные читателю статьи из журналов, библиотека подбирает литературу на отдельные темы из своего фонда. По требованию сотрудника заказываются библиографические списки в б-ке Наркомтяжпрома в Москве, в БАН СССР. Библиотека систематически устраивает маленькие календарные выставки» ${ }^{25}$. Под библиографической работой в ряде библиотек понималась роспись статей классиков марксизма-ленинизма и «описание журналов по мере поступления и их систематизацию» ${ }^{26}$. В библиотеках Грузинского филиала АН СССР помощь читателям осуществлялась в виде устных переводов статей и устных справок. В остальных библиотеках справочная работа не велась. Впрочем, под справочной работой иногда понимали «информацию к текущим событиям и революционным торжествам» ${ }^{27}$. Такая работа велась интенсивно во всех библиотеках. Например, в Фундаментальной библиотеке Азербайджанского филиала АН СССР подбиралась литература по темам «Стахановское движение в нефтяной промышленности» и «Социалистическое строительство в Азербайджанской ССР». В библиотеке Химического научно-исследовательского института Грузинского филиала устраивались выставки «к отдельным главам истории ВКП(б), справочная работа ведется с газетными статьями» ${ }^{28}$. В библиотеке Уральского филиала была организована 21 выставка, «посвященная Конституции, октябрьским торжествам и др.», «увеличился спрос на политическую литературу <...> за счет чтения классиков марксизма-ленинизма и истории партии» ${ }^{29}$.

Отсутствие систематической методической помощи со стороны головной библиотеки становится очевидным, когда речь заходит о каталогах периферийных библиотек. Алфавитные каталоги в форме картотек или книг присутствовали во всех библиотеках, но кое-где они отражали только часть фонда. С систематическим все было сложнее. Поскольку головная библиотека не настаивала на унификации каталогов в своей сети, разные библиотеки вели его по разным системам: большая часть библиотек систематизировала издания по десятичной системе Добржинского, Библиотека института энциклопедий и словарей по инструкциям Книжной палаты, Библиотека института геологии Армянского филиала $\mathrm{AH}$ СССР - по таблицам Шамурина, библиотека Геофизического института Грузинского филиала по “Classification decimale universelle" Bruxelles.

\footnotetext{
25 Научный Архив БЕН РАН. Оп. 2. Д. 2. Л. 19. НаучныЙ Архив БЕН РАН. ОП. 2. Д. 2. Л. 23. НаучныЙ Архив БЕН РАН. ОП. 2. Д. 2. Л. 17. Научный Архив БЕН РАН. Оп. 2. Д. 2. Л. 1, 6-31. Научный Архив БЕН РАН. Оп. 2. Д. 2. Л. 30 об.
}

В ряде библиотек систематический каталог имелся только на отечественные издания, в иных систематического каталога вообще не было, зато был предметный, а в Библиотеке института энциклопедий и словарей - даже топографический. И, хотя в БАН уже сложилась своя собственная методика ведения каталогов, периферийные библиотеки ей охвачены не были.

Осуществлять методическую помощь периферийным библиотекам своей сети должна была БАН. В мае 1935 г. на заседании Президиума АН был заслушан доклад сотрудника Комитета филиалов и баз Я. Ф. Шарова об обследовании Кольской базы АН СССР. По докладу Президиум АН СССР вынес постановление: «Поручить директору БАН командировать на 3 месяца библиотечного работника на Базу для приведения в порядок библиотеки (инвентаризация, каталогизация и т. д.)» ${ }^{30}$. Методическая помощь периферийным библиотекам посредством длительных командировок ложилась тяжким бременем и на сотрудников, и на бюджет БАН. 27 июня 1936 г. на распорядительном заседании Президиума АН СССР было рассмотрено ходатайство Комитета по филиалам и базам об установлении в БАН должности инструктора по библиотекам филиалов и баз. Ходатайство было отклонено, а БАН было предложено (как и раньше) «организовать инструктаж путем выезда ответственного работника библиотеки на места в те филиалы и базы, где этот инструктаж требуется» ${ }^{31}$. Но инструкторовметодистов в периферийные библиотеки направляли в редких случаях: «Общее инструктирование - только письменное из-за недостатка финансирования», - докладывал в 1936 г. директор БАН И. И. Яковкин ${ }^{32}$.

Руководство Комитета по развитию филиалов и баз и БАН было в курсе проблем библиотек периферийных академических учреждений. Возможно, именно поэтому 31 декабря 1937 г. старшим консультантом по заведованию филиалами и базами назначают Ф. И. Понировского, до этого момента возглавлявшего Московское отделение БАН, которое и стало впоследствии Библиотекой по естественным наукам. На новом поприще «доцент экономических наук» (именно так Ф. И. Понировский именует себя в анкете) развивает бурную деятельность. Ведь помимо общего инспектирования и руководства он способен оказать квалифицированную методическую помощь библиотекам академических учреждений. Он лично знаком с директором БАН

\footnotetext{
30 Архив Российской академии наук. Ф. 2. Оп. 6. Д. 3. Л. 166. Протоколы заседаний Президиума АН СССР за 1936 год № 1-19.

Архив Российской академии наук. Ф. 2. Оп. 6. Д. 5а. л. 37-38 [протокол № 3 2/6/5а л. 37-38]. Протоколы заседаний Президиума Академии Наук СССР за 1936 год (май - июль). 32 Санкт-Петербургский филиал Архива Российской академии наук. Ф. 158. Оп. 3 (1936). Д. 83. Л. 30. Материалы по проектированию здания БАН в Москве.
} 
И. И. Яковкиным и не исключено, что именно директор БАН лоббировал его перевод на эту должность, чтобы избавиться от необходимости посылать своих сотрудников на места. В целях установления «живой» связи филиальных библиотек с сектором сети Ф. И. Понировский постоянно ездит по стране с консультациями по библиотекам и в начале 1940 г. занимает должность руководителя Консультационноинспекторской группы Комитета филиалов и баз AН СССР. В январе он отбывает в Узбекистан для организации Узбекского филиала Академии наук СССР и за «энергичную и инициативную работу по выполнению решения Президиума АН СССР об открытии Узбекского филиала АН» в марте получает благодарность Президиума АН СССР и премию в размере 500 рублей. В апреле Ф. И. Понировский едет в Таджикский и Казахстанский филиалы, в июне его «бросают» на укрепление базы на Кольском полуострове, об итогах этой командировки он докладывает лично президенту АН СССР В. Л. Комарову. В сентябре он инспектирует Уральский филиал, а 15 октября 1940 г. его увольняют с должности по неизвестной причине. В декабре 1940 г. Туркменский, Таджикский, Узбекский и Уральский филиалы консультируют и инспектируют уже другие сотрудники ${ }^{33}$.

В конце 1930 - начале 1940-х гг. развитие и деятельность филиалов и баз становится приоритетным направлением в организации работы АН СССР. В 1940 г. была даже организована специальная выставка, приуроченная к годовому отчету о деятельности периферийных учреждений АН СССР ${ }^{34}$. Президент Академии наук СССР В. Л. Комаров 14 апреля 1941 г. на заседании Комитета филиалов и баз высказался о предназначении региональных учреждений АН СССР: «Я всегда давал филиалам такое указание, что они должны работать на свою республику, филиал должен быть слугой своей республики... В Москве Академия наук есть идеологическая надстройка над классовой борьбой. Мы от народа далеки, между нами и народом существует прослойка. В филиалах же этой прослойки между ними и народом нет. Поэтому филиалы ближе к народу, ближе к жизни, ближе к производству, ближе к сельскому хозяйству, ближе ко всему, чем живет страна» ${ }^{35}$.

Несмотря на ощутимую поддержку сотрудников Комитета по заведованию филиалами и базами АН СССР в деле укрепления работы периферийных академических учреждений и их библиотек,

\footnotetext{
з3 Архив Российской академии наук. Ф. 188 (1931-1942). Д. 832. Л. 1, 15, 26, 53, 83, 120. Распоряжения по Комитету филиалов и баз.

Архив Российской академии наук. Ф. 188 (1931-1942). Д. 832. Л. 1, 7. Распоряжения по Комитету филиалов и баз. Архив Российской академии наук. Ф. 188. Оп. 1 (19311942). Д. 978. Л. 15. Протокол и стенограмма заседания Комитета филиалов и баз о работе филиалов за 1940 год.
}

уровень информационного и методического обеспечения библиотек не соответствовал требованиям ученых на местах. О том, что «инструктирование» и комплектование библиотек новых академических учреждений велись неудовлетворительно, свидетельствует письмо, поступившее директору БАН И. И. Яковкину в марте 1939 г. из библиотеки Уральского филиала АН СССР. Это второе письмо, так как на предыдущее библиотекари из филиала ответа не получили. Оно содержит вопросы по библиотечной работе: как производить оценку книг, как вести учет книжного фонда, как проводить инвентаризацию иностранных изданий и пр. Письмо содержит также просьбу по возможности выслать дублетные экземпляры иностранной периодики за старые годы для докомплектования, иностранные каталоги и проспекты - для составления заявок на иностранные издания, а также справочные издания.

Специалисты в области организации и управления библиотечным делом, в том числе и сотрудник Библиотечной комиссии при Президиуме АН СССР Б. Н. Бачалдин, неоднократно отмечали, что руководить постоянно растущей сетью библиотек региональных филиалов и баз АН СССР из Ленинграда было делом довольно затруднительным. В результате Сектору сети специальных библиотек, помимо комплектования, была передана и функция обслуживания библиотек филиалов и баз. Заботой Сектора сети становится и методическая работа с ними. В планах работы Сектора сети специальных библиотек, начиная с 1941 г., предусматривалось разрешение многих из имевшихся проблем. В Архиве БЕН РАН - правопреемнике Сектора сети специальных библиотек АН СССР - сохранился «План работы группы библиотек филиалов АН СССР на 1941 год», который приводится в Приложении 1.

Начавшаяся Великая Отечественная война не позволила реализовать большинство пунктов приведенного плана в 1941 г.

\section{Сеть библиотек филиалов и баз АН СССР в военные годы}

Деятельность представителей Комитета филиалов и баз, несомненно, давала свои плоды. Особенно это сказалось в годы войны, когда столичные академические учреждения эвакуировались на уже имеющиеся базы и филиалы. Эвакуация московских и ленинградских академических учреждений способствовала развитию периферийных филиалов и баз, расширению их библиотек и росту национальных научных кадров.

Работа с иногородними библиотеками академи ческих учреждений не прекращалась и в годы войны, но претерпела существенные изменения. 
С началом войны БАН СССР в Ленинграде перестала в прежнем объеме выполнять свои функции, вся литература для нее складировалась в Секторе сети специальных библиотек в Москве и обрабатывалась его сотрудниками. Значительно сократилось число сотрудников Сектора сети. С августа 1941 г. заведующая Группой филиалов Юзефа Руфиновна Мокиевская была назначена заведующей Сектором сети специальных библиотек. Именно благодаря ей не прервалось комплектование библиотек филиалов и баз в военное время. В декабре 1941 г. в объяснительной записке к штатной ведомости Сектора сети она обосновывает сохранение Группы комплектования следующим образом: «Ввиду того, что отбор и получение обязательного экземпляра из Книжной палаты продолжается, также как продолжается поступление иностранной литературы и журналов в библиотеки сети и Ленинграда, работа по отправке дополнительной литературы по уехавшим институтам и комплектование Среднеазиатских филиалов, считаю необходимым оставить в группе комплектования 3 человек» ${ }^{36}$ В военное время в библиотеки филиалов, баз и станций Сектор сети специальных библиотек направлял только отечественную литературу, приобретаемую путем покупки. Комплектование иностранной литературой в годы войны по поручению Президиума АН СССР осуществлял Книжный отдел при Президиуме АН СССР под руководством Рафа Карповича Карахана. Несмотря на недоступность из блокадного Ленинграда материалов Отдела иностранного комплектования БАН, который до войны сосредотачивал в своих руках все данные о заказах и зарубежных книготорговых организациях, он за считанные месяцы первого военного года установил контакты со всеми библиотеками академических учреждений, включая и библиотеки отдаленных филиалов и баз, получил от них списки для заказа иностранных журналов и успешно сформировал заказ на иностранные периодические издания на 1942 г. Об этом в письме от 9 сентября 1941 г. он сообщает президенту АН СССР В. Л. Комарову ${ }^{37}$.

Руководители академий наук оккупированных Украины и Белоруссии выразили в 1942 г. желание передать свои ассигнования в червонной валюте в Книжный отдел, с тем чтобы обеспечить библиотеки своих учреждений иностранной литературой, изданной в годы войны. Поэтому впервые началась централизованная подписка иностранной литературы для библиотек академий наук союзных республик через Книжный отдел Президиума АН СССР. В целях сохранения иностранной литературы, заказанной на средства Академий наук Белоруссии и Украины,

36 Научный Архив БЕН РАН. Оп. 2. Д. 2. Л. 1, 1 об.

37 Архив Российской академии наук. Ф. 277. Оп. 3. Д. 84. Л. 7. Отчеты заведующего Книжным отделом АН СССР Карахана Р. о работе отдела. предотвращения ее утери и передачи другим организациям Р. К. Карахан направляет письмо в Главлит с просьбой пересылать всю зарубежную литературу для БССР, УССР и оккупированных территорий в Книжный отдел АН СССР. Зная сложности периферийных библиотек при формировании заказов на иностранную литературу, Р. К. Карахан несколько раз направлял письма и докладные записки руководству Академии наук СССР, продвигая идею как можно более быстрого информирования научных работников на местах о новой литературе, выпущенной зарубежными издательствами. Благодаря его активности «по вопросу организации научно-технической информации в связи с возросшим спросом страны в условиях военного времени и для максимального содействия НИР учреждений АН Президиум постановляет: выпускать в каждом отделении бюллетени с аннотациями специальных журналов и книг не реже одного раза в месяц; публиковать в журналах АН систематически обзоры всех важнейших научных трудов в советской и иностранной печати; КО обеспечить издание бюллетеня по общим вопросам организации науки и научной практики» ${ }^{38}$. Это бесспорно способствовало полноценному комплектованию фондов библиотек иногородних филиалов.

В 1943 г. ввиду огромного объема работы и малочисленности списочного состава Книжного отдела в помощь ему при Секторе сети специальных библиотек была образована Группа иностранного комплектования. Она работала столь успешно, что продолжила свою деятельность и после войны. В условиях нехватки средств на выписку новой литературы начали применяться новые методы обеспечения периферийных институтов научной информацией. Совместно с Лабораторией фотографии и кинематографии Сектор сети специальных библиотек провел опытные работы по тиражированию этих текстов на киноленте, и «ввиду полного успеха полученных результатов было начато обслуживание такого рода снимками библиотеки Таджикского филиала» ${ }^{39}$. Большое внимание уделялось среднеазиатским филиалам. Именно там во время войны находились многие академические учреждения Москвы и Ленинграда. Только в Ташкенте находились институты истории, почвенный, сейсмологический, истории права, истории материальной культуры, мирового хозяйства и мировой политики, мировой литературы им. Горького. Научные работы велись в областях исследования культуры узбекского народа, развития энергетики, изучения нефтяных месторождений, засоления почв. Составлялась трехтомная «История

38 Архив Российской академии наук. Ф. 277. Оп. 3. Д. 84. Л. 7. Отчеты заведующего Книжным отделом АН СССР Карахана Р. о работе отдела.

39 Архив Российской академии наук. Ф. 465. Оп. 1. Д. 60. Л. 2. Письма в управление пропаганды и агитации ЦК ВКП(б) о выписке иностранной литературы и записка о совместной работе Книжного отдела с научной секцией ВОКСа. 
Узбекистана», активно проводилась подготовка местных научных кадров. Вся эта деятельность не могла быть успешной без своевременного снабжения новой научной литературой и отличной работы библиотек. По инициативе директора БАН И. И. Яковкина для организации методической поддержки, «для инструктирования и надлежащей связи с библиотеками филиалов Академии наук СССР в Алма-Ата, Ашхабаде, Сталинабаде и Фрунзе» в этот регион на полтора месяца была направлена главный библиотекарь Сектора сети Г. М. Лукомская ${ }^{40-41}$.

В 1943 г. отмечается рост периферийных учреждений АН СССР и преобразование филиалов АН СССР в союзных республиках в национальные академии наук. 5 января 1943 г. был открыт Киргизский филиал АН СССР, который возглавил академик К. И. Скрябин. Решение о его создании было принято руководством АН СССР в декабре 1942 г. в Свердловске. В то трудное время было принципиально важно выявление ресурсов стратегического сырья - об этом говорится в принятом постановлении: «отметив наличие в Киргизской ССР больших, но слабо изученных ресурсов стратегического сырья, признать необходимым организацию филиала АН в Киргизии» ${ }^{42}$. Киргизский филиал был организован в рекордно короткий срок - за 8 месяцев. В декабре 1942 г. президент АН СССР докладывает В. М. Молотову об организации Киргизского филиала, а в августе 1943 г. филиал начинает свою работу. Уже в первый год своего существования Киргизский филиал объединил 170 сотрудников в 4 вновь созданных институтах Геологическом, Химическом, Биологическом и Институте киргизского языка и литературы. Этому немало способствовал тот факт, что в г. Фрунзе (ныне Бишкек) тогда располагались эвакуированные из Москвы академические институты и их сотрудники, в том числе академик А. А. Борисяк, который приложил большие усилия, чтобы обеспечить новый филиал помещениями для работы, приборами и литературой ${ }^{43}$. Для комплектования библиотеки этого филиала Сектором сети специальных библиотек было приобретено более 4000 старых изданий, и вся эта литература была обработана и закаталогизирована для того, чтобы создать в новой библиотеке основу будущего каталога ${ }^{44}$.

40 Научный Архив БЕН РАН. Оп. 4 дел по личному составу. Д. 4. Приказы по личному составу за 1943-1944 гг. Л. 18.

Архив Российской академии наук. Ф. 1845. Оп. 1. Д. 20. Л. 14. Отчеты о работе групп и отделов Сектора за 1943 год. 42 Архив Российской академии наук. Ф. 188. Оп. 1 (19411945). Д. 27. Л. 9. Материалы об открытии Киргизского филиала $\mathrm{AH}$.

43 Архив Российской академии наук. Ф. 188. Оп. 1 (19411945). Д. 27. Л. 7. Материалы об открытии Киргизского филиала АН.

44 Архив Российской академии наук. Ф. 188. Оп. 1 (19411945). Д. 27. Л. 9. Материалы об открытии Киргизского филиала $\mathrm{AH}$.
«В том же 1943 году товарищ Сталин принимает личное участие в решении вопроса о преобразовании Армянского и Узбекского филиалов в самостоятельные Академии наук» ${ }^{45}$. На заседании Президиума Академии наук СССР было принято Постановление СНК СССР о реорганизации Узбекского филиала АН СССР в Академию наук Узбекской ССР. Торжественное открытие было назначено на 4 ноября. Месяцем позже в Национальную академию наук был преобразован Армянский филиал АН СССР. Первое собрание АН Армянской ССР было проведено 23 ноября. Тогда же было принято решение о реорганизации Горно-таежной станции в Дальневосточную базу АН СССР, ей было передано имущество бывшего Дальневосточного филиала АН СССР и библиотека Приморского филиала Всесоюзного географического общества.

В 1943 г. 9 филиалов АН СССР (Азербайджанский, Армянский, Грузинский, Казахский, Киргизский, Таджикский, Туркменский, Узбекский и Уральский) и 2 базы АН СССР (Дальневосточная и база по изучению (евера) объединяли 32 института, 32 самостоятельных сектора и отдела, 3 заповедника, 8 ботанических садов, 3 астрономических обсерватории, 4 сейсмических станции, Бюро антисейсмического строительства, 5 музеев, 2 стационара и другие научно-исследовательские учреждения, в которых работало 1562 научных работника ${ }^{46}$.

В трудное военное время продолжались инспекторские и консультационные поездки в филиалы: в январе 1942 г. представители Комитета филиалов и баз выезжают в среднеазиатские филиалы и на Базу по изучению Севера ${ }^{47}$.

На основе эвакуированных в годы войны в регионы институтов, научных сотрудников и библиотек институтов, ряд баз и филиалов превратились в полноценные научные центры АН СССР, а республиканские филиалы - в академии наук союзных республик. Руководство АН СССР было в начале войны эвакуировано вместе с рядом институтов, в том числе Математического и Физического вместе с их библиотеками, в Казань. Летом 1943 г. началась реэвакуация этих учреждений в места прежнего расположения. С целью сохранения научной базы в Поволжье Совнарком и обком ВКП(б) Татарской АССР выступили с ходатайством об организации Средне-Волжского филиала АН в Казани, для чего в Москву была направлена делегация, возглавляемая секретарем Татобкома Г. Ф. Шафиковым. 24 сентября 1943 г. Президиум АН СССР принял решение об организации

\footnotetext{
Архив Российской академии наук. Ф. 188. Оп. 1 (19411945). Д. 50а. Л. 2. «10-летие филиалов и баз».

Архив Российской академии наук. Ф. 188. Оп. 1 (19411945). Д. 50а. Л. 1. «10-летие филиалов и баз».

Архив Российской академии наук. Ф.188. Оп.1 (19411945). Д. 4. Л. 6. Распоряжения по Совету филиалов и баз AH CCCP.
} 
в Казани филиала АН СССР. Двумя годами позже, 13 апреля 1945 г., была открыта библиотека Казанского филиала АН СССР (рис. 14). С самого первого дня комплектование и методическое руководство этой библиотекой было возложено на Сектор сети специальных библиотек.

В феврале 1944 г. по докладу академика А. А. Скочинского было принято решение об организации Западно-Сибирского филиала (ЗСФ) АН СССР. Докладчик и стал председателем его Президиума. В этом же году начинается перестройка школы для здания филиала, которая была закончена только в 1947 г. Ни один филиал не учреждался так долго, как Западно-Сибирский. Еще в 11 ноября 1931 г. в Москве состоялась Конференция по учреждению комплексных баз АН СССР в Западной и Восточной Сибири, на которой было принято следующее постановление: «Параграф 1: приступить к практическому осуществлению решения ЦИК, обеспечив начало работ в 1 квартале 1932 года; Параграф 2: поставить перед Западно-Сибирским филиалом задачи изучить производительные силы края, наличие полезных ископаемых, для чего основать 7 институтов; Параграф 6: Для развертывания сети филиалов и проведения научно-исследовательской работы филиал должен получить средства, достаточные для обеспечения строительства здания, оборудования для лабораторий и кабинетов и библиотеки, и на текущее содержание; Параграф 9: немедленно организовать работу по подысканию помещения» ${ }^{48}$.
База для учреждения филиала АН СССР в Западной Сибири была уже подготовлена: в 1931 г. там функционировало 42 научноисследовательских института отраслевых ведомств, в том числе 16 промышленных, 18 сельскохозяйственных, 3 транспортных, остальные - социально-культурного направления, в которых работало 600 научных работников. На этой основе и решили создать авторитетную научную организацию, которая бы рассматривала теоретические проблемы, связанные с развитием хозяйства всего края. Задачей ближайших лет ставилась организация 7 институтов; а конкретно в 1932 г. - Геофизического в Новосибирске, Химической соляной станции в Кулунде, станции по изучению Севера в Томске и Абаканской комплексной станции по изучению леса и полезных ископаемых. Таким образом, в 1932 г. должны были начать работу 1 институт и 3 станции, которые впоследствии должны были быть развернуты в самостоятельные институты. Организация энергетического, геохимического и биологического институтов была делом будущего. Финансирование этого грандиозного проекта возлагалось частично на Академию наук СССР, частично - на местный бюджет, но львиная доля расходов падала на хозяйственные организации Западно-Сибирского края. Было много планов, предложений, комитетов и комиссий, но не было ни денег, ни помещения, ни квалифицированных кадров ${ }^{49}$. Даже временного помещения и жилья

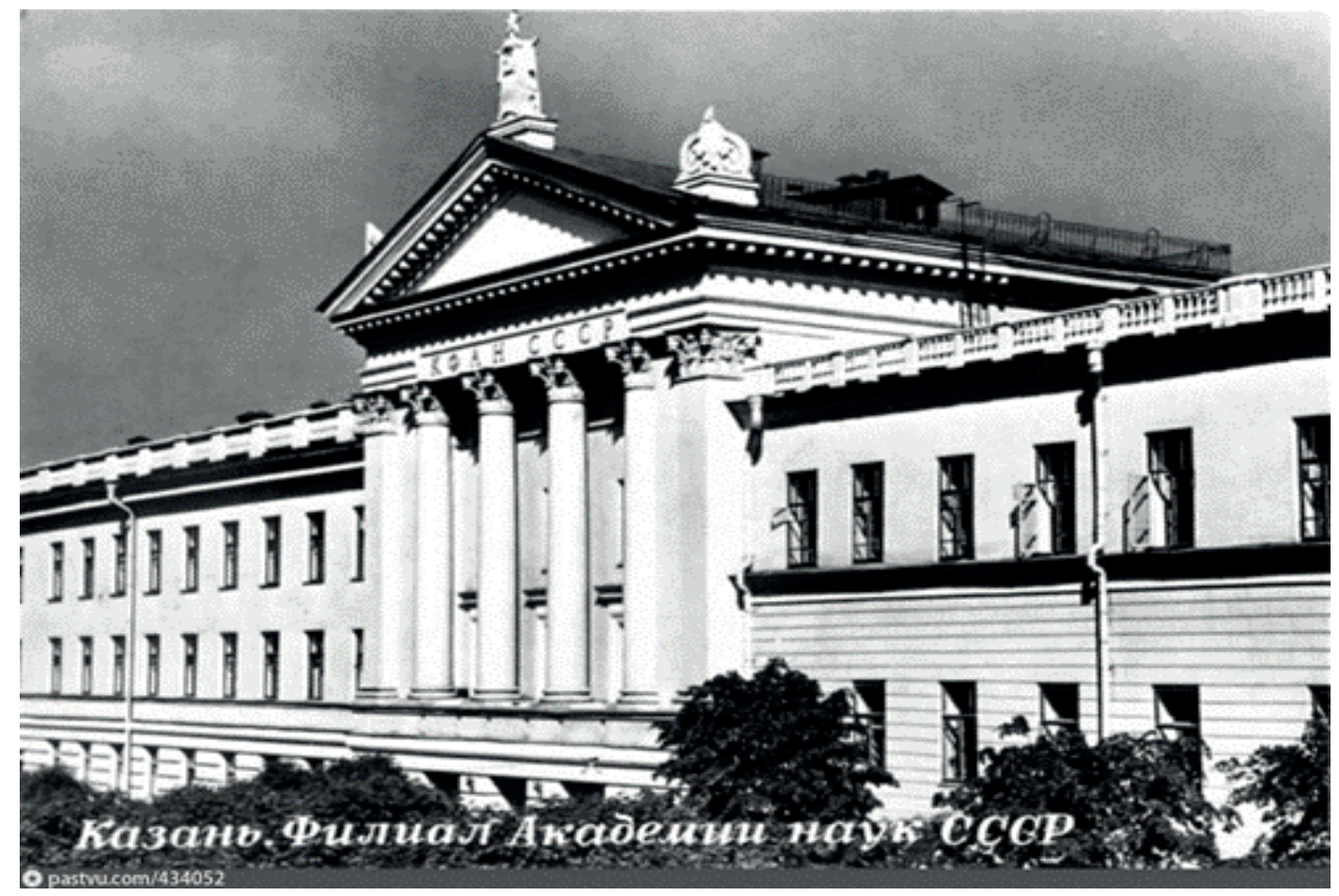

Pис. 14. Здание Казанского филиала АН СССР с библиотекой

48 Архив Российской академии наук. Ф. 188. Оп. 1 (19311935). Д. 7. Л. 34. Протоколы заседания Конференции по организации в Западной Сибири филиала Академии наук CCCP.
49 Архив Российской академии наук. Ф. 188. Оп. 1 (19311935). Д. 7. Л. 10, 15, 22. Протоколы заседания Конференции по организации в Западной Сибири филиала Академии наук СССР. 
для приезжих научных сотрудников найдено не было. Академик А. Е. Ферсман подошел к делу организации Западно-Сибирского филиала более практично: его предложение состояло в том, что пока в Ленинграде ведется длительная подготовительная работа ${ }^{50}$, нужно широко развивать экспедиционную деятельность, создать обширную сеть экспедиций с подведением под них материальной базы. Академик С. А. Лебедев в свою очередь предложил подготавливать кадры для будущей базы АН СССР в местных вузах. В течение 1932 и 1933 гг. академик В. П. Волгин тщетно пытался решить с местными властями вопрос о финансировании и предоставлении помещений, но нашлись средства только на Кулундинскую соляную станцию, на научные институты денег не было. Организация этого филиала была отложена на неопределенное время. Только в июне 1943 г. заведующий Комитетом филиалов и баз АН СССР Б. Н. Митрейкин сообщил президенту АН СССР В. Л. Комарову о том, что «поддержано ходатайство организации ЗСФ» ${ }^{51}$. Бригада под председательством А. А. Скочинского провела организационную работу по созданию ЗСФ в Новосибирске в составе горно-геологического, химико-металлургического, транспортноэнергетического и медико-биологического институтов ${ }^{52}$. В структуру филиала была сразу же включена библиотека, заполнена штатная должность библиотекаря - им стал библиограф А. П. Кулаков. Комплектование новой научной библиотеки взял на себя, конечно же, Сектор сети специальных библиотек.

В 1944 г. происходило дальнейшее развертывание работы в Москве Сектора сети специальных библиотек - как по линии восстановления работы библиотек, возвращенных из эвакуации, так и по обслуживанию новых точек. Отдел отечественного комплектования Сектора сети снабжал литературой 64 библиотеки, в том числе 40 московских, 13 библиотек филиалов и баз и 11 библиотек Ленинграда. В этом году количество комплектуемых библиотек увеличилось на 8 единиц за счет Морской гидрофизической лаборатории ${ }^{53}$, Группы карт при Институте этнографии, Лаборатории № 2, Института русского

\footnotetext{
50 Архив Российской академии наук. Ф. 188. Оп. 1 (19311935). Д. 7. Л. 23, 25. Протоколы заседания Конференции по организации в Западной Сибири филиала Академии наук СССР

51 Архив Российской академии наук. Ф. 188. Оп. 1 (19311935). Д. 7. Л. 21. Протоколы заседаний Комиссии по филиалам и базам АН СССР.

52 Архив Российской академии наук. Ф. 188. Оп. 1 (19311935). Д. 7. Л. 21. Протоколы заседаний Комиссии по филиалам и базам АН СССР.

53 Фонд библиотеки Морской гидрофизической лаборатории Сектор сети специальных библиотек начал комплектовать начиная с апреля 1944 г. Эта крошечная библиотека обслуживала свою базу - Черноморскую гидрофизическую станцию, комплектуя для нее литературу и формируя «передвижки». До конца 1944 г. в Крым было отправлено 3 передвижных выставки, 124 книги и 1 подписка на газету «Правда».
}

языка, Института леса, Западно-Сибирского филиала, Дальневосточной базы и Памирской биологической станции ${ }^{54}$. Комплектование библиотек последних трех учреждений началось только в ноябре 1944 г. Также было значительно расширено комплектование Кольской базы, до ее реэвакуации из Сыктывкара литература направлялась в Ботанический сад Кировска (Мурманская область).

Библиотеки филиалов и баз комплектовались исключительно покупной отечественной литературой, на приобретение которой выделялись значительные суммы. Объемы финансирования на комплектование отечественными монографиями в 1944 г. представлены в таблице 6.

Все монографии направлялись в библиотеки филиалов и баз с 2 каталожными карточками, что облегчало создание каталогов на местах. Периодические издания из обязательного экземпляра (3 названия) получал только Казахский филиал, остальные получали отечественные периодические издания по подписке, которую проводил Сектор сети специальных библиотек. Для периферийных библиотек закупались и книжные коллекции из частных собраний. В 1944 г. для Киргизского филиала была приобретено книжное собрание Е. Д. Войтинской 35 изданий классиков марксизма, для Коми филиала - 20 библиотечных единиц и 4 справочных издания для Таджикского филиала.

В 1944 г. функция комплектования иностранной литературой перешла к Сектору сети специ альных библиотек. Иностранной литературой сектор комплектовал 62 академические библиотеки, в том числе 9 библиотек филиалов и баз. Сведения о поступлениях в филиалы иностранной литературы в разных отчетах отличаются. В таблице 7 приведены цифры из сводки отдела иностранного комплектования Сектора сети специальных библиотек за 1944 г. В отчете Сектора сети указаны следующие данные за этот год: в 9 библиотек филиалов и баз направлено 35 монографий, в 7 библиотек - 38 библиотечных единиц периодики - без росписи по библиотекам.

В целях информирования иногородних библиотек о выходившей, а также поступившей в страну иностранной литературе Сектор сети выпустил два номера «Бюллетеня новых поступлений иностранной литературы», которые содержали 569 названий, что облегчило выписку изданий из-за границы на следующий год.

На 1 января 1945 г. в АН СССР входило 53 института, 16 лабораторий, 35 станций, 31 комиссия, 15 музеев. Вне Москвы и Ленинграда Сектор сети специальных библиотек обслуживал 22 библиотеки на местах (табл. 8).

54 Архив Российской академии наук. Ф. 1845. Оп. 1. Д. 21. Л. 4, 7. Отчет о работе Сектора за 1944 год. 
Финансирование библиотек на комплектование отечественными монографиями в 1944 г. [36]

\begin{tabular}{|c|c|c|c|c|}
\hline $\begin{array}{c}\text { Наименование } \\
\text { филиала или базы }\end{array}$ & $\begin{array}{l}\text { Обязательный } \\
\text { экземпляр }\end{array}$ & Дар & $\begin{array}{c}\text { Покупка биб. } \\
\text { единиц }\end{array}$ & $\begin{array}{l}\text { Сумма } \\
\text { в рублях }\end{array}$ \\
\hline Казахский филиал & 67 & 65 & 997 & 6306 \\
\hline Киргизский филиал & 1 & 62 & 2089 & 14990 \\
\hline Татарский филиал & 17 & 53 & 844 & 9019 \\
\hline Туркменский филиал & 1 & 44 & 800 & 5137 \\
\hline $\begin{array}{l}\text { Западно- } \\
\text { Сибирский филиал }\end{array}$ & 25 & 1 & 122 & 4735 \\
\hline База Коми & 55 & 33 & 594 & 7342 \\
\hline Кольская база & 1 & 10 & 222 & 1555 \\
\hline $\begin{array}{l}\text { Дальневосточная } \\
\text { база }\end{array}$ & - & 5 & 123 & 1134 \\
\hline $\begin{array}{l}\text { Памирская } \\
\text { биологическая } \\
\text { станция }\end{array}$ & - & 2 & 40 & 307 \\
\hline $\begin{array}{l}\text { Биологическая станция, } \\
\text { Листвянка }\end{array}$ & - & 4 & 43 & 279 \\
\hline Армянский филиал & - & 3 & 49 & 772 \\
\hline $\begin{array}{l}\text { Абастуманская } \\
\text { обсерватория }\end{array}$ & 3 & 3 & 75 & 1128 \\
\hline Азербайджанский филиал & - & - & 12 & 67 \\
\hline
\end{tabular}

Источник: Архив Российской академии наук. Ф. 1845. Оп. 1. Д. 22. Л. 4. Отчеты о работе отделов Сектора за 1944 год

таблица 7

Комплектование библиотек филиалов и баз АН СССР иностранными изданиями в 1944 г.

\begin{tabular}{|l|c|c|}
\hline \multicolumn{1}{|c|}{$\begin{array}{c}\text { Наименование филиала } \\
\text { или базы }\end{array}$} & $\begin{array}{c}\text { Монографии } \\
\text { (выписано/получено) }\end{array}$ & $\begin{array}{c}\text { Периодика } \\
\text { (выписано) }\end{array}$ \\
\hline Казахский филиал & $21 / 3$ & 4 \\
\hline Киргизский филиал & $24 /-$ & 7 \\
\hline Татарский филиал & $37 / 1$ & 3 \\
\hline Туркменский филиал & $13 /-$ & - \\
\hline Западно-Сибирский филиал & Не выписывал & - \\
\hline База Коми & $2 / 10$ предыдущий заказ & 3 \\
\hline Кольская база & $6 / 4$ & 15 \\
\hline Дальневосточная база & $16 / 1$ & - \\
\hline Уральский филиал & $82 / 5$ & \\
\hline
\end{tabular}

Источник: Архив Российской академии наук. Ф. 1845. Оп. 1. Д. 22. Л. 4. Отчеты о работе отделов Сектора за 1944 год.

Продолжилась покупка книжных коллекций для периферийных библиотек у частных лиц (табл. 9).

Выписка иностранной литературы на 1945 г. была увеличена в несколько раз. Отдел иностранной литературы Сектора сети специальных библиотек постоянно жаловался на плохое качество заявок, поступающих с мест. Из-за отсутствия в периферийных библиотеках библиографических спра- вочников заявки требовали серьезной библиографической доработки. Часто сотрудники отдела иностранной литературы проводили заказ зарубежных изданий на основе созданной в отделе учетной картотеки текущей научной литературы ${ }^{55}$ и по заявкам ученых московских институтов, 55 Для информации иногородних библиотек о новинках
литературы целые разделы этой картотеки переписывались и рассылались на места. 
Финансирование библиотек на комплектование отечественными монографиями в 1945 г.

\begin{tabular}{|c|c|c|c|c|c|}
\hline \multirow{2}{*}{$\begin{array}{c}\text { Наименование } \\
\text { филиала или базы }\end{array}$} & \multicolumn{3}{|c|}{ Монографии } & \multicolumn{2}{|c|}{ Периодика } \\
\hline & $\begin{array}{l}\text { Обязательный } \\
\text { экземпляр }\end{array}$ & $\begin{array}{c}\text { Покупка/сумма } \\
\text { в рублях }\end{array}$ & Дар & $\begin{array}{l}\text { Обязательный } \\
\text { экземпляр }\end{array}$ & Дар \\
\hline Казахский & 64 & 1112 / 9366 & 31 & 8 & 5 \\
\hline Киргизский & - & 738 / 6440 & 15 & - & 6 \\
\hline Татарский & 6 & $865 / 7417$ & 21 & - & 5 \\
\hline Туркменский & 1 & $846 / 7449$ & 19 & - & 5 \\
\hline $\begin{array}{l}\text { Западно- } \\
\text { Сибирский }\end{array}$ & 159 & 755 / 8682 & 24 & 14 & 19 \\
\hline База Коми & 23 & $646 / 5869$ & 16 & - & 6 \\
\hline Кольская база & - & 489 / 4903 & 15 & - & 10 \\
\hline $\begin{array}{l}\text { Дальневосточная } \\
\text { база }\end{array}$ & - & $470 / 5019$ & 16 & - & 7 \\
\hline $\begin{array}{l}\text { Памирская } \\
\text { биологическая } \\
\text { станция }\end{array}$ & - & 178 / 1996 & 4 & - & 1 \\
\hline $\begin{array}{l}\text { Биологическая станция } \\
\text { Листвянка }\end{array}$ & - & $3 / 270$ & - & - & - \\
\hline АФИ & - & 64 / 740 & 1 & - & - \\
\hline $\begin{array}{l}\text { Абастуманская } \\
\text { обсерватория }\end{array}$ & - & $183 / 1219$ & - & - & - \\
\hline Уральский & - & $461 / 3835$ & 4 & 1 & 6 \\
\hline
\end{tabular}

Источник: Архив Российской академии наук. Ф. 1845. Оп. 1. Д. 26. Л. 13. Отчеты о работе отделов Сектора сети за 1945 год.

Сведения о покупке литературы у частных лиц в 1945 г.

\begin{tabular}{|l|l|l|l|}
\hline \multicolumn{1}{|c|}{ Ф. И. О. владельца } & \multicolumn{1}{|c|}{ Специальность } & \multicolumn{1}{|c|}{$\begin{array}{l}\text { Количество } \\
\text { библиотеч- } \\
\text { ных единиц }\end{array}$} \\
\hline Бродский А. И. & Химия & Западно-Сибирский & 278 \\
\hline Орлов Ю. А. & Химические журналы & Киргизский & 40 \\
\hline Кацнельсон & Химия & Казахский & 2405 \\
\hline Ортенберг Л. И. & Горное дело, геология & Казахский & 2194 \\
\hline Новиков В. Ф. & Справочная литература & Казахский & 43 \\
\hline Профессор Парухин & Металлургия & Казахский & 2654 \\
\hline Курнаков Н. С. & Журналы & Казахский & 317 \\
\hline
\end{tabular}

Источник: Архив Российской академии наук. Ф. 1845. Оп. 1. Д. 26. Л. 18, 19. Отчеты о работе отделов Сектора сети за 1945 год.

не дожидаясь получения заявок с мест. При этом большое значение придавалось выписке энциклопедий и справочников ${ }^{56}$. Одновременно периферийным библиотекам рассылались списки изданий, заказанных по инициативе сектора в порядке «активного комплектования». Количество

56 Архив Российской академии наук. Ф. 1845. Оп. 1. Д. 25. Л. 11. Отчеты о работе Сектора сети за 1945 год. заказанных в 1945 г. для библиотек филиалов и баз зарубежных изданий: 2058 монографий и 521 годовой комплект журналов ${ }^{57}$.

Сектором сети специальных библиотек в военные годы продолжалась библиографическая и методическая работа в интересах периферийных

57 Архив Российской академии наук. Ф. 1845. Оп. 1. Д. 26. Л. 19. Отчеты о работе отделов Сектора сети за 1945 год. 


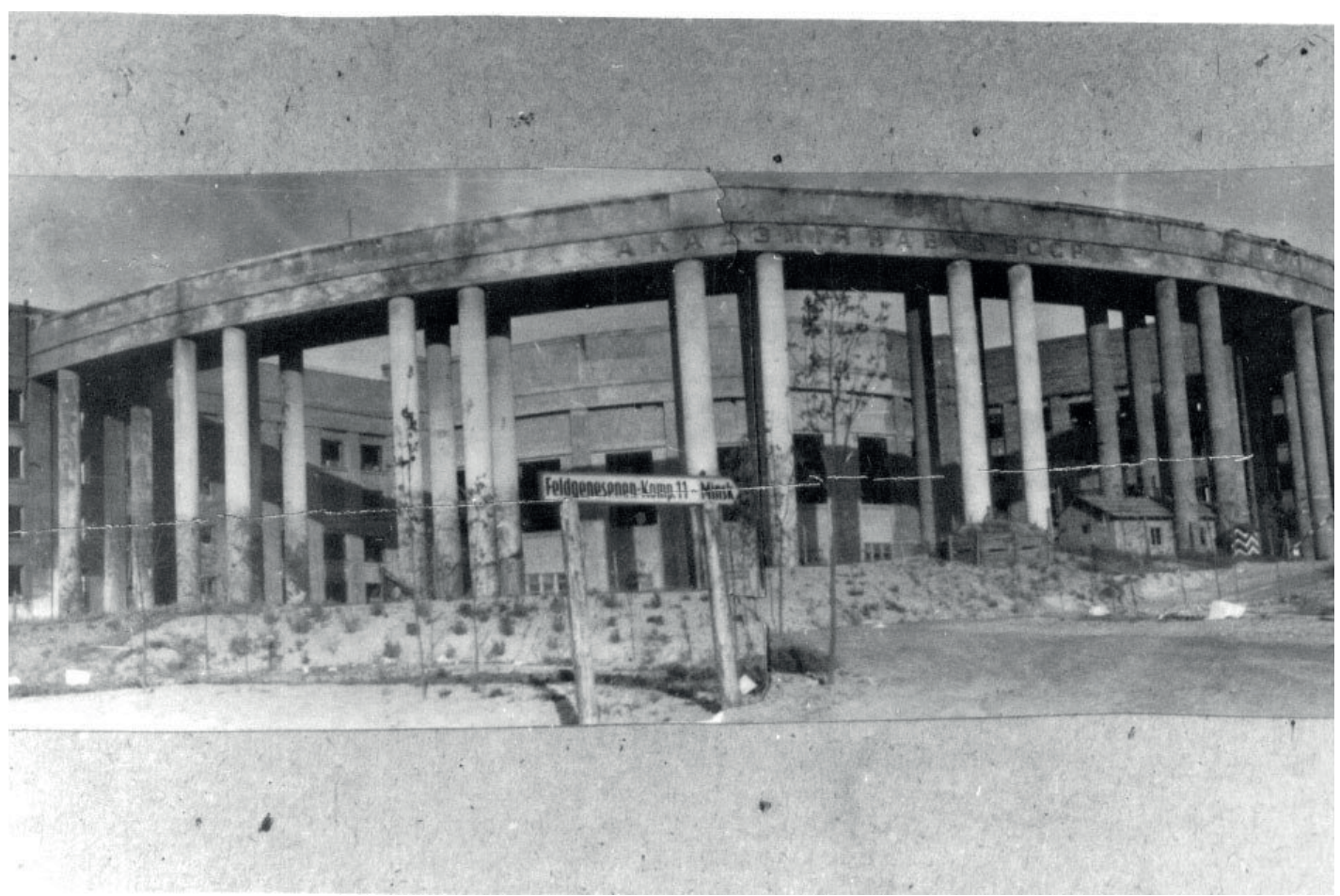

Puc. 14. Разрушенное здание Президиума АН Белоруссии и библиотеки АН БССР Источник: http://vminsk.by/wp-content/uploads/2019/01/19-01-01-02.jpg

библиотек. В 1945 г. был составлен указатель изданий баз и филиалов АН СССР, состоящий из 4500 названий. Были также подготовлены и оформлены для печати 10 алфавитных указателей по отдельным филиалам и базам и один сводный алфавитный указатель по фамилиям авторов и редакторов. De visu было проверено 161 название и «запредметизированы» разделы по геологии - 900 названий, по биологии - 949, по химии $-334^{58}$.

Для оказания методической помощи в библиотеки Казахского и Киргизского филиалов в 1945 г. была командирована зав. библиотекой Энергетического института Е. В. Траубе. Ознакомившись с их работой, она оказала им практическую помощь, о чем сделала сообщение на производственном совещании. Совещание постановило: в Секторе сети специальных библиотек необходимо иметь сотрудника, специально ведающего библиотеками баз и филиалов. Практика методико-библиографической поддержки иногородних библиотек, прерванная войной, снова стала актуальной.

Сектор сети специальных библиотек АН СССР в последние дни войны и послевоенные годы активно помогал в создании библиотечных фондов и методическими консультациями создаваемым библиотекам Академии наук Молдавии и разрушенным войной академическим библиотекам Белоруссии и Украины. После освобождения оккупированных территорий начался процесс

58 Архив Российской академии наук. Ф. 1845. Оп. 1. Д. 26. л. 11. Отчеты о работе отделов Сектора сети за 1945 год. восстановления книжных фондов библиотек учреждений Украинской и Белорусской академий наук (рис. 14). Московские библиотеки Сектора сети специальных библиотек - отделения биологических, химических, геологических наук и другие выделили из дублетных фондов 15000 библиотечных единиц для Академии наук Белоруссии, библиотека ФИ АН - 650 популярных изданий для Академии наук Украины.

В марте 1944 г. распоряжением № 244 по Академии наук СССР директорам институтов Отделения биологических наук и БАН в Ленинграде было предписано изыскать возможность выделения оборудования и литературы Институту ботаники УССР, что и было сделано. Летом 1945 г. для библиотеки АН Белорусской ССР из фонда библиотеки Отделения геолого-географических наук было выделено 514 библиотечных единиц, а из библиотеки Института почвоведения - 1000 библиотечных единиц. Молдавскому географическому институту Сектор сети специальных библиотек передал 300 библиотечных единиц, а Харьковскому сельскохозяйственному институту - 500 единиц литературы. Сотни названий монографий и журналов было передано библиотекам Польши ${ }^{59}$.

Практика полноценного комплектования библиотек иногородних филиалов и методической помощи им продолжалась и интенсивно расширялась в послевоенные годы.

59 Архив Российской академии наук. Ф. 1845. Оп. 1. Д. 27. Л. 54. Отчеты о работе библиотек Сектора сети за 1945 год. 


\section{Заключение}

Приведенные в статье данные и их анализ позволяют понять, какую колоссальную работу вели сотрудники Сектора сети специальных библиотек при развертывании библиотек филиалов и баз АН СССР перед войной и в военные годы. Созданная эффективная система обеспечения литературой периферийных академических библиотек, методов управления и контроля их деятельности, изучения информационных потребностей на местах позволила прийти к созданию на базе Сектора сети крупнейшей академической информационно-библиотечной системы в стране - Библиотеки по естественным наукам.

Наряду с изменениями в стране изменилась и библиотечная структура нынешней Российской академии наук. Из централизованной библиотечной системы БЕН АН СССР, объединявшей к 1980 г. около 200 академических библиотек на всей территории СССР, в ЦБС БЕН РАН теперь 50 библиотек институтов РАН Московского региона [5]. Многие из библиотек системы в регионах приобрели организационную и финансовую самостоятельность. Однако профессиональные связи с коллегами из академических библиотек бывших союзных республик и возникшими на основе баз и филиалов библиотеками научных центров и отделений РАН в БЕН РАН сохраняются.

На пороге юбилея РАН и БЕН РАН нам есть что вспомнить, поэтому хочется как можно точнее и объемнее зафиксировать память о большой работе коллег-предшественников. Эта статья отражает лишь один аспект деятельности названных учреждений в сложнейший период нашей истории.

\section{Список источников}

1. Организация советской науки в 1926-1932 гг. : сб. док. / отв. ред. Б. Е. Быховский ; Акад. наук СССР, Ин-т истории естествознания и техники, Ленингр. отдние. Ленинград : Наука. Ленингр. отд-ние, 1974. 406 с.

2. Устав Академии наук Союза Советских Социалистических Республик. 1935 г. URL: http://www. arran.ru/data/pdf/ustav1935.pdf (дата обращения: 10.12.2020).

3. Бардин И.П. Филиалы академии наук СССР на службе народного хозяйства (к 20-летию существования системы филиалов Академии Наук СССР). Вестник АН СССР. 1952. № 11. С. 65-81.

4. Труды Библиотеки Академии наук и Фундаментальной библиотеки общественных наук Академии наук СССР. Т. 3. Москва, Ленинград : Изд-во Акад. наук СССР, 1958. 328 с.

5. Отделы в институтах РАН // Библиотека по естественным наукам Российской академии наук. URL: https://www.benran.ru/lib_seti1.html (дата обращения: 10.12.2020).

Статья поступила в редакцию 10.12.2020

Получена после доработки 18.01.2021

Принята для публикации 15.02.2021

\section{References}

1. Bykhovsky B. E. (ed.) Organizatsiia sovetskoi nauki v 1926-1932 gg.: sb. dok. [Organization of Soviet Science in 1926-1932: doc. coll.]. Leningrad, Nauka, Leningrad. Dep., 1974. 406 p. (In Russ).

2. Ustav Akademii nauk Soyuza Sovestskikh Sotsialisticheskikh Respublik. 1935 g. [Charter of the USSR Academy of Sciences. 1935]. URL: http://www.arran.ru/ data/pdf/ustav1935.pdf (accessed 10.12.2020). (In Russ).

3. Bardin I. P. Branches of the USSR Academy of Sciences in the service of the national economy (to the 20th anniversary of the existence of the system of branches of the USSR Academy of Sciences). Vestnik AN SSSR, 1952, 11: 65-81. (In Russ).

4. Trudy Biblioteki Akademii nauk i Fundamental'noi biblioteki obshchestvennykh nauk Akademii nauk SSSR. [Proceedings of the Library of the Academy of Sciences and the Fundamental Library on Social Sciences of the USSR Academy of Sciences]. Vol. 3. Moscow, Leningrad, Publ. House of the USSR Acad. of Sciences, 1958. 328 p. (In Russ).

5. Departments at Institutes of RAS. Biblioteka po estestvennym naukam Rossiiskoi Akademii nauk. URL: https:// www.benran.ru/lib_seti1.html (accessed 10.12.2020). (In Russ).

Received 10.12.2020

Revised 18.01.2021

Accepted 15.02.2021 


\section{Приложение 1}

ПЛАН РАБОТЫ ГРУППЫ БИБЛИОТЕК ФИЛИАЛОВ АН СССР НА 1941 Г.

«Группа библиотек филиалов АН СССР ставит своей задачей всестороннее обслуживание библиотек филиалов, в первую очередь наиболее удаленных от центра.

В 1941 году группа обслуживает 10 точек/из них 7 полностью/.

Обслуживание проводится по следующим линиям:

1. Комплектование.

Комплектование на основании тематических планов Ин-тов филиалов производится путем покупки, получения в обмен и дар и частично из обязательного экземпляра. На комплектование библиотек в 1941 году запланированы следующие суммы: ТФАН - 15.500, КФАН - 13.000, ТУРКФАН - 12.000, АО - 4.800, ГИАРМ - 4.000, ЭИАРМ - 4.000, АБНИ /с июля/ 4.000, МИР - 2.500, УзФАН 60 - 1000. ИТОГО - 60.800.

По комплектованию библиотеки делятся на три категории:

а/ библиотеки, комплектуемые как новой, так и старой литературой,

б/ библиотеки, комплектуемые только новой литературой,

в/ библиотеки, комплектуемые только старой литературой / Бот. ин-т АрмФАНа/

2. Обработка книг: индексация и описание /каталожные карточки/

3. Библиографическая помощь: а) посылка информационной литературы - бюллетени, персоналии; б) справки; в) тематическая библиография

4. Методическое руководство: а) обеспечение методическими пособиями, б) инструктаж на местах, в) инструктаж в Москве

5. Обеспечение предметами библиотечной техники

Из-за отсутствия штата углубить и расширить план работы не представляется возможным. Подписано: Ю. Мокиевская» ${ }^{61}$.

\footnotetext{
60 Приведенные аббревиатуры являются принятыми в Секторе сети специальных библиотек сокращенными обозначениями наименований библиотек филиалов и баз (сиглами).

61 Научный Архив БЕН РАН. Оп. 2. Д. 2. Л. 1, 1 об.
} 